\title{
1 Glutamine deprivation triggers NAGK-dependent hexosamine salvage
}

2 Sydney L. Campbelli,2, Clementina Mesaros ${ }^{3}$, Luke Izzo ${ }^{1,2}$, Hayley Affronti ${ }^{1,2}$, Michael Noji1,2,

3 Bethany E. Schaffer ${ }^{4}$, Tiffany Tsang ${ }^{1,2}$, Kathryn Sun ${ }^{5}$, Sophie Trefely ${ }^{1,2,6}$, Salisa Kruijning ${ }^{1,2}$,

4 John Blenis ${ }^{4}$, Ian A. Blair ${ }^{3}$, Kathryn E. Wellen ${ }^{1,2,7}$

$5 \quad{ }^{1}$ Department of Cancer Biology, ${ }^{2}$ Abramson Family Cancer Research Institute, ${ }^{3}$ Department of

6 Systems Pharmacology and Translational Therapeutics, University of Pennsylvania,

7 Philadelphia, PA 19104; ${ }^{4}$ Meyer Cancer Center and Department of Pharmacology, Weill Cornell

8 Medicine, New York, NY 10021; ${ }^{5}$ Pancreatic Cancer Research Center, Perelman School of

9 Medicine, University of Pennsylvania, Philadelphia, PA 19104; ${ }^{6}$ Center for Metabolic Disease

10 Research, Department of Microbiology and Immunology, Lewis Katz School of Medicine,

11 Temple University, Philadelphia, PA 19140. ${ }^{7}$ Corresponding author.

\section{Abstract}

13 Tumors frequently exhibit aberrant glycosylation, which can impact cancer progression and

14 therapeutic responses. The hexosamine biosynthesis pathway (HBP) produces uridine

15 diphosphate N-acetylglucosamine (UDP-GIcNAc), a major substrate for glycosylation in the cell.

16 Prior studies have identified the HBP as a promising therapeutic target in pancreatic ductal

17 adenocarcinoma (PDA). The HBP requires both glucose and glutamine for its initiation. The

18 PDA tumor microenvironment is nutrient poor, however, prompting us to investigate how

19 nutrient limitation impacts hexosamine synthesis. Here, we identify that glutamine limitation in

20 PDA cells suppresses de novo hexosamine synthesis but results in increased free GlcNAc

21 abundance. GlcNAc salvage via N-acetylglucosamine kinase (NAGK) is engaged to feed UDP-

22 GIcNAc pools. NAGK expression is elevated in human PDA, and NAGK deletion from PDA cells

This manuscript has been co-submitted with Kim et al. (2020), "Pancreatic Cancers Scavenge Hyaluronic Acid to Support Growth." 
impairs tumor growth in mice. Together, these data identify an important role for NAGKdependent hexosamine salvage in supporting PDA tumor growth.

\section{Introduction}

Altered glycosylation is frequently observed in malignancies, impacting tumor growth as well as immune and therapeutic responses (Akella et al., 2019; Mereiter et al., 2019; Munkley, 2019). Several types of glycosylation, including O-GlcNAcylation and N-linked glycosylation, are dependent on the glycosyl donor uridine diphosphate N-acetylglucosamine (UDP-GlcNAc), which is synthesized by the hexosamine biosynthesis pathway (HBP). The HBP branches off from glycolysis with the transfer of glutamine's amido group to fructose-6-phosphate (F-6-P) to generate glucosamine-6-phosphate (GlcN-6-P), mediated by the rate limiting enzyme glutamine-fructose-6-phosphate transaminase (GFPT1/2). The pathway further requires acetyl-CoA, ATP, and uridine triphosphate (UTP) to ultimately generate UDP-GIcNAc. O-

37 GlcNAcylation, the addition of a single N-acetylglucosamine (GlcNAc) moiety onto a serine or threonine residue of intracellular proteins, is upregulated in multiple cancers (Akella, et al.,

39 2019). Targeting O-GlcNAcylation suppresses the growth of breast, prostate, and colon cancer tumors (Caldwell et al., 2010; Ferrer et al., 2017; Gu et al., 2010; Guo et al., 2017; Lynch et al.,

41 2012). Similarly, highly branched N-glycan structures are sensitive to HBP flux and are 42 upregulated in malignant tissue, and targeting the relevant Golgi GIcNAc transferase enzymes 43 can limit tumor growth and metastasis in vivo (Granovsky et al., 2000; Li et al., 2008; Zhou et 44 al., 2011). Thus, improved understanding the regulation of the HBP in cancer could point 45 towards novel therapeutic strategies.

This manuscript has been co-submitted with Kim et al. (2020), "Pancreatic Cancers Scavenge Hyaluronic Acid to Support Growth." 
Pancreatic ductal adenocarcinoma (PDA) is a deadly disease with a 5-year survival rate of $9 \%$ and a rising number of annual deaths (Rahib et al., 2014) (ACS Cancer Facts and Figures 2019, NIH SEER report 2019). Mutations in KRAS occur in nearly all cases of human PDA and drive extensive metabolic reprogramming in cancer cells. Enhanced flux into the HBP was identified as a primary metabolic feature mediated by mutant KRAS in PDA cells (Ying et al., 2012). Hypoxia, a salient characteristic of the tumor microenvironment (Lyssiotis and Kimmelman, 2017), was shown to further promote expression of glycolysis and HBP genes in pancreatic cancer cells (Guillaumond et al., 2013). Notably, the glutamine analog 6-diazo-5-oxo-Lnorleucine (DON), which inhibits the HBP, suppressed PDA metastasis and sensitized PDA tumors to anti-PD1 therapy (Sharma et al., 2020). DON has also been reported to sensitize PDA cells to the chemotherapeutic gemcitabine in vitro (Chen et al., 2017). Additionally, a recently developed inhibitor targeting the HBP enzyme phosphoacetylglucosamine mutase 3 (PGM3) enhances gemcitabine-mediated reduction of xenograft tumor growth in vivo (Ricciardiello et al., 2020). Thus, the HBP may represent a therapeutic target in PDA, although the regulation of UDP-GIcNAc synthesis and the optimal strategies to target this pathway for therapeutic benefit in PDA remain poorly understood.

An outstanding question is the impact of the tumor microenvironment on UDP-GIcNAc synthesis. The HBP has been proposed as a nutrient-sensing pathway since its rate-limiting step, mediated by GFPT1/2, requires both glutamine and the glycolytic intermediate fructose-6phosphate (Denzel and Antebi, 2015). In hematopoietic cells, glucose deprivation limits UDPGlcNAc levels and dramatically reduces levels of the N-glycoprotein IL3Ra at the plasma membrane in a manner dependent on the HBP (Wellen et al., 2010). Similarly, O-GlcNAcylation of certain nuclear-cytosolic proteins, including cancer-relevant proteins such as Myc and Snail, This manuscript has been co-submitted with Kim et al. (2020), "Pancreatic Cancers Scavenge Hyaluronic Acid to Support Growth." 
et al., 2008; Park et al., 2010; Swamy et al., 2016). Yet, the PDA tumor microenvironment is

71 thought to be particularly nutrient poor, owing to its characteristic dense stroma (Halbrook and

72 Lyssiotis, 2017). This raises the question of how nutrient deprivation impacts the synthesis of

73 UDP-GIcNAc and its utilization for glycosylation. Understanding how PDA cells regulate these

74 processes under nutrient limitation could identify therapeutic vulnerabilities. In this study, we

75 investigated the impact of nutrient deprivation on the HBP and glycosylation in PDA cells,

76 identifying a key role for hexosamine salvage through the enzyme $\mathrm{N}$-acetylglucosamine kinase

77 (NAGK) in PDA tumor growth.

\begin{tabular}{|l|l|l|l|l|}
\hline \multicolumn{1}{|c|}{ KEY RESOURCES TABLE } & \multicolumn{1}{|c|}{$\begin{array}{l}\text { Source or } \\
\text { (species) or } \\
\text { resource } \\
\text { reference }\end{array}$} & Designation line (Homo \\
sapiens) & MIA PaCa-2 & ATCC & CRL-1420 & Additional information \\
\hline $\begin{array}{l}\text { cell line (Homo } \\
\text { sapiens) }\end{array}$ & PANC-1 & ATCC & CRL-1469 & \\
\hline $\begin{array}{l}\text { cell line (Homo } \\
\text { sapiens) }\end{array}$ & HPAC & ATCC & CRL-2119 & \\
\hline $\begin{array}{l}\text { cell line (Homo } \\
\text { sapiens) }\end{array}$ & AsPC-1 & ATCC & CRL-1682 & \\
\hline $\begin{array}{l}\text { cell line (Homo } \\
\text { sapiens) }\end{array}$ & BxPC-3 & ATCC & CRL-1687 & \\
\hline $\begin{array}{l}\text { cell line (Homo } \\
\text { sapiens) }\end{array}$ & HCT 116 & ATCC & CCL-247 & \\
\hline
\end{tabular}

This manuscript has been co-submitted with Kim et al. (2020), "Pancreatic Cancers Scavenge Hyaluronic Acid to Support Growth." 


\begin{tabular}{|c|c|c|c|c|}
\hline $\begin{array}{l}\text { cell line (Homo } \\
\text { sapiens) }\end{array}$ & SW480 & ATCC & CCL-228 & \\
\hline Plasmid & $\begin{array}{l}\text { lentiCRISPR } \\
\text { v2 }\end{array}$ & Addgene & 52961 & \\
\hline Antibody & $\begin{array}{l}\text { O-GIcNAc } \\
\text { CTD1106 }\end{array}$ & Cell Signaling & 9875S & \\
\hline Antibody & tubulin & Sigma & T6199 & \\
\hline Antibody & HSP60 & Cell Signaling & $12165 S$ & \\
\hline Antibody & NAGK & $\begin{array}{l}\text { Atlas } \\
\text { Antibodies }\end{array}$ & HPA035207 & \\
\hline Antibody & NAGK & Proteintech & 15051-1-AP & \\
\hline Antibody & $\begin{array}{l}\text { AKT } \\
\text { phosphos47 } \\
3\end{array}$ & Cell Signaling & 4060 & \\
\hline Antibody & Viniculin & Sigma & V9264 & \\
\hline $\begin{array}{l}\text { Chemical } \\
\text { compound }\end{array}$ & $\begin{array}{l}{[U-13 C]-} \\
\text { glucose }\end{array}$ & $\begin{array}{l}\text { Cambridge } \\
\text { Isotopes }\end{array}$ & CLM-1396-1 & \\
\hline $\begin{array}{l}\text { Chemical } \\
\text { compound }\end{array}$ & 13C GlcNAc & $\begin{array}{l}\text { Omicron } \\
\text { Biochemicals }\end{array}$ & GLC-006 & \\
\hline Strain & $\begin{array}{l}\mathrm{NCr} \text { nude } \\
\text { mice }\end{array}$ & Taconic & $\begin{array}{l}\text { CrTac:NCr- } \\
\text { Foxn1nu }\end{array}$ & \\
\hline $\begin{array}{l}\text { Sequenced- } \\
\text { based reagent }\end{array}$ & $\begin{array}{l}\text { GFPT1 } \\
\text { forward }\end{array}$ & This paper & $\begin{array}{l}\text { RT-qPCR } \\
\text { primers }\end{array}$ & $\begin{array}{l}\text { CTCTGGCTTTGGTGGATA } \\
\text { AA }\end{array}$ \\
\hline $\begin{array}{l}\text { Sequenced- } \\
\text { based reagent }\end{array}$ & $\begin{array}{l}\text { GFPT1 } \\
\text { reverse }\end{array}$ & This paper & $\begin{array}{l}\text { RT-qPCR } \\
\text { primers }\end{array}$ & GCAACCACTTGCTGAAGA \\
\hline $\begin{array}{l}\text { Sequenced- } \\
\text { based reagent }\end{array}$ & $\begin{array}{l}\text { NAGK } \\
\text { forward }\end{array}$ & This paper & $\begin{array}{l}\text { RT-qPCR } \\
\text { primers }\end{array}$ & $\begin{array}{l}\text { GTGCTCATATCTGGAACA } \\
\text { GG }\end{array}$ \\
\hline $\begin{array}{l}\text { Sequenced- } \\
\text { based reagent }\end{array}$ & $\begin{array}{l}\text { NAGK } \\
\text { reverse }\end{array}$ & This paper & $\begin{array}{l}\text { RT-qPCR } \\
\text { primers }\end{array}$ & $\begin{array}{l}\text { ACCCTCATCACCCATCAT } \\
\text { A }\end{array}$ \\
\hline $\begin{array}{l}\text { Sequenced- } \\
\text { based reagent }\end{array}$ & $\begin{array}{l}\text { HPRT } \\
\text { forward }\end{array}$ & This paper & $\begin{array}{l}\text { RT-qPCR } \\
\text { primers }\end{array}$ & $\begin{array}{l}\text { ATTATGCCGAGGATTTGG } \\
\text { AA }\end{array}$ \\
\hline $\begin{array}{l}\text { Sequenced- } \\
\text { based reagent }\end{array}$ & $\begin{array}{l}\text { HPRT } \\
\text { reverse }\end{array}$ & This paper & $\begin{array}{l}\text { RT-qPCR } \\
\text { primers }\end{array}$ & $\begin{array}{l}\text { CCCATCTCCTTCATGACA } \\
\text { TCT }\end{array}$ \\
\hline
\end{tabular}

This manuscript has been co-submitted with Kim et al. (2020), "Pancreatic Cancers Scavenge Hyaluronic Acid to Support Growth." 


\begin{tabular}{|c|c|c|c|c|}
\hline $\begin{array}{l}\text { Sequenced- } \\
\text { based reagent }\end{array}$ & $\begin{array}{l}\text { RPL19 } \\
\text { forward }\end{array}$ & This paper & $\begin{array}{l}\text { RT-qPCR } \\
\text { primers }\end{array}$ & $\begin{array}{l}\text { CAAGAAGGAGGAGATCA } \\
\text { TCAAG }\end{array}$ \\
\hline $\begin{array}{l}\text { Sequenced- } \\
\text { based reagent }\end{array}$ & $\begin{array}{l}R P L 19 \\
\text { reverse }\end{array}$ & This paper & $\begin{array}{l}\text { RT-qPCR } \\
\text { primers }\end{array}$ & $\begin{array}{l}\text { ATCACAGAGGCCAGTAT } \\
\text { GTA }\end{array}$ \\
\hline $\begin{array}{l}\text { Sequenced- } \\
\text { based reagent }\end{array}$ & $\begin{array}{l}\text { sgMGAT5 } \\
\text { mouse } \\
\text { forward }\end{array}$ & $\begin{array}{l}\text { Doench et al., } \\
2016\end{array}$ & $\begin{array}{l}\text { CRISPR } \\
\text { deletion } \\
\text { primers }\end{array}$ & $\begin{array}{l}\text { CACCGGCTGTCATGACA } \\
\text { CCAGCGTA }\end{array}$ \\
\hline $\begin{array}{l}\text { Sequenced- } \\
\text { based reagent }\end{array}$ & $\begin{array}{l}\text { sgMGAT5 } \\
\text { mouse } \\
\text { reverse }\end{array}$ & $\begin{array}{l}\text { Doench et al., } \\
2016\end{array}$ & $\begin{array}{l}\text { CRISPR } \\
\text { deletion } \\
\text { primers }\end{array}$ & $\begin{array}{l}\text { AAACTACGCTGGTGTCAT } \\
\text { GACAGCC }\end{array}$ \\
\hline $\begin{array}{l}\text { Sequenced- } \\
\text { based reagent }\end{array}$ & $\begin{array}{l}\text { sgNAGK\#1 } \\
\text { forward }\end{array}$ & $\begin{array}{l}\text { Doench et al., } \\
2016\end{array}$ & $\begin{array}{l}\text { CRISPR } \\
\text { deletion } \\
\text { primers } \\
\end{array}$ & $\begin{array}{l}\text { CACCGTTGACGTAGCCG } \\
\text { ATATCATG }\end{array}$ \\
\hline $\begin{array}{l}\text { Sequenced- } \\
\text { based reagent }\end{array}$ & $\begin{array}{l}\text { sgNAGK\#1 } \\
\text { reverse }\end{array}$ & $\begin{array}{l}\text { Doench et al., } \\
2016\end{array}$ & $\begin{array}{l}\text { CRISPR } \\
\text { deletion } \\
\text { primers } \\
\end{array}$ & $\begin{array}{l}\text { AAACCATGATATCGGCTA } \\
\text { CGTCAAC }\end{array}$ \\
\hline $\begin{array}{l}\text { Sequenced- } \\
\text { based reagent }\end{array}$ & $\begin{array}{l}\text { sgNAGK\#2 } \\
\text { forward }\end{array}$ & $\begin{array}{l}\text { Doench et al., } \\
2016\end{array}$ & $\begin{array}{l}\text { CRISPR } \\
\text { deletion } \\
\text { primers } \\
\end{array}$ & $\begin{array}{l}\text { CACCGTGCTTGGTGTGC } \\
\text { GATCCAGT }\end{array}$ \\
\hline $\begin{array}{l}\text { Sequenced- } \\
\text { based reagent }\end{array}$ & $\begin{array}{l}\text { sgNAGK\#2 } \\
\text { reverse }\end{array}$ & $\begin{array}{l}\text { Doench et al., } \\
2016\end{array}$ & $\begin{array}{l}\text { CRISPR } \\
\text { deletion } \\
\text { primers }\end{array}$ & $\begin{array}{l}\text { AAACACTGGATCGCACAC } \\
\text { CAAGCAC }\end{array}$ \\
\hline $\begin{array}{l}\text { Sequenced- } \\
\text { based reagent }\end{array}$ & $\begin{array}{l}\text { sgNAGK\#3 } \\
\text { forward }\end{array}$ & $\begin{array}{l}\text { Doench et al., } \\
2016\end{array}$ & $\begin{array}{l}\text { CRISPR } \\
\text { deletion } \\
\text { primers } \\
\end{array}$ & $\begin{array}{l}\text { CACCGCTCTACACCCCC } \\
\text { ATAGATCG }\end{array}$ \\
\hline $\begin{array}{l}\text { Sequenced- } \\
\text { based reagent }\end{array}$ & $\begin{array}{l}\text { sgNAGK\#3 } \\
\text { reverse }\end{array}$ & $\begin{array}{l}\text { Doench et al., } \\
2016\end{array}$ & $\begin{array}{l}\text { CRISPR } \\
\text { deletion } \\
\text { primers } \\
\end{array}$ & $\begin{array}{l}\text { AAACCGATCTATGGGGG } \\
\text { TGTAGAGC }\end{array}$ \\
\hline $\begin{array}{l}\text { Sequenced- } \\
\text { based reagent }\end{array}$ & $\begin{array}{l}\text { siRNA non- } \\
\text { targeting } \\
\text { control }\end{array}$ & $\begin{array}{l}\text { Santa Cruz } \\
\text { Biotechnology }\end{array}$ & SC-37007 & \\
\hline $\begin{array}{l}\text { Sequenced- } \\
\text { based reagent }\end{array}$ & siGALE & $\begin{array}{l}\text { Santa Cruz } \\
\text { Biotechnology }\end{array}$ & SC-78950 & \\
\hline $\begin{array}{l}\text { Sequenced- } \\
\text { based reagent }\end{array}$ & siGNE & $\begin{array}{l}\text { Santa Cruz } \\
\text { Biotechnology }\end{array}$ & SC-60693 & \\
\hline
\end{tabular}

This manuscript has been co-submitted with Kim et al. (2020), "Pancreatic Cancers Scavenge Hyaluronic Acid to Support Growth." 


\begin{tabular}{|l|l|l|l|l|} 
& & & \\
$\begin{array}{l}\text { Sequenced- } \\
\text { based reagent }\end{array}$ & siGALK2 & $\begin{array}{l}\text { Santa Cruz } \\
\text { Biotechnology }\end{array}$ & SC-90002 & \\
\hline
\end{tabular}

\section{Cell culture}

Cells were cultured in DMEM high glucose (Gibco, 11965084) with 10\% calf serum (Gemini GemCell U.S. Origin Super Calf Serum, 100-510), unless otherwise noted. Glucose- or glutamine-restricted media was prepared using glucose, glutamine, and phenol red free DMEM (Gibco, A1443001) supplemented with glucose (Sigma-Aldrich, G8769), glutamine (Gibco, 25030081), and dialyzed fetal bovine serum (Gemini, 100-108). For all glutamine restriction experiments except S2.3 D, cells were plated 2-3x more densely for the nutrient restricted condition samples to achieve similar confluency at the experiment endpoint. $1 \%$ oxygen levels were achieved by culturing cells in a Whitley H35 Hypoxystation (Don Whitley Scientific). ATCC names and numbers for the cell lines used in this study are: MIA PaCa-2 (ATCC\# CRL-1420),

91 PANC-1 (ATCC\# CRL-1469), HPAC (ATCC\# CRL-2119), AsPC-1 (ATCC\# CRL-1682), BxPC-3

92 (ATCC\# CRL-1687), HCT 116 (ATCC\# CCL-247), and SW480 (ATCC\# CCL-228). All cells were the GenePrint 10 System (Promega, B9510).

\section{Generation of CRISPR cell lines}

sgRNA sequences targeting NAGK or Mgat5 from the Brunello and Brie libraries (Doench et al.,

97 2016) were cloned into the lentiCRISPRv2 vector (Sanjana, Shalem et al., 2014). Lentivirus was produced in 293T cells according to standard protocol. Cells were then infected with the CRISPR lentivirus and selected with puromycin. Cells were plated at very low density into 96 This manuscript has been co-submitted with Kim et al. (2020), "Pancreatic Cancers Scavenge Hyaluronic Acid to Support Growth." 
100

101

102

103

104

105

106

107

108

109

110

111

112

113

114

115

116

117

118

119

120

121

122

well plates to establish colonies generated from single cell clones. Mgat5 gene disruption was validated by qPCR and L-PHA binding. NAGK gene disruption was validated by qPCR, western blot, and ${ }^{13} \mathrm{C}-$ GICNAc tracing. Seven NAGK knockout clonal cell lines established from three different sgRNAs, four in PANC-1 cells and three in MIA PaCa-2 cells, were chosen for use in the study. Please see table at end of methods for primer sequences of guides used.

\section{Western blotting}

For protein extraction from cells, cells were kept on ice and washed three times with PBS, then scraped into PBS and spun down at $200 \mathrm{~g}$ for 5 minutes. The cell pellet was resuspended in 50 $100 \mu \mathrm{L}$ RIPA buffer [1\% NP-40, 0.5\% deoxycholate, 0.1\% SDS, $150 \mathrm{mM} \mathrm{NaCl}, 50 \mathrm{mM}$ Tris plus protease inhibitor cocktail (Sigma-Aldrich, P8340) and phosSTOP (Sigma-Aldrich, 04906845001)] and lysis was allowed to continue on ice for 10 minutes. Cells were sonicated with a Fisherbrand Model 120 Sonic Dismembrator (Fisher Scientific, FB120A110) for three pulses of 20 seconds each at $20 \%$ amplitude. Cell lysate was spun down at $15,000 \mathrm{~g}$ for 10 minutes at $4^{\circ} \mathrm{C}$ and supernatant was transferred to a new tube. For protein extraction from tissue, the sample was resuspended in $500 \mu \mathrm{L}$ RIPA buffer and homogenized using a Tissuelyser (Qiagen, 85210) twice for 30s at $20 \mathrm{~Hz}$. Following incubation on ice for 10 minutes the same procedure was followed as for cells. For both cells and tissue, lysate samples were stored at $-80^{\circ} \mathrm{C}$ until analysis by immunoblot. All blots were developed using a LI-COR Odyssey CLx system. Antibodies used in this study were: O-GIcNAc CTD110.6 (Cell Signaling 9875S), tubulin (Sigma T6199), HSP60 (Cell Signaling 12165S), NAGK (Atlas Antibodies, HPA035207), and PARP (Cell Signaling 9532).

For blots showing the mobility shift for NAGK in low glutamine, samples were prepared in lysis buffer containing $50 \mathrm{mM}$ Tris pH 8.0, $150 \mathrm{mM} \mathrm{NaCl}, 0.5 \%$ IGEPAL CA-630 (Sigma, I3021), 1 This manuscript has been co-submitted with Kim et al. (2020), "Pancreatic Cancers Scavenge Hyaluronic Acid to Support Growth." 
123

124

125

126

127

128

129

130

131

132

133

mM PMSF, $1.5 \mu \mathrm{M}$ aprotinin, $84 \mu \mathrm{M}$ leupeptin, $1 \mu \mathrm{M}$ pepstatin $\mathrm{A},-/+10 \mathrm{mM} \mathrm{NaF}$ and $20 \mathrm{mM}$ $\mathrm{Na}_{3} \mathrm{VO}_{4}$ as indicated. To visualize the NAGK mobility shift in response to low glutamine, $20 \mu \mathrm{g}$ total protein per sample was separated across $12.5 \mathrm{~cm}$ of $11 \%$ SDS-PAGE resolving space under reducing conditions using the large electrophoresis systems available from C.B.S. Scientific until approximately $3 \mathrm{~cm}$ of separation was obtained between the 25 and $37 \mathrm{kDa}$ protein standards (Bio-Rad; 1610375). Using electrophoresis, proteins were transferred (30 V, $4^{\circ} \mathrm{C}$, overnight) to $0.45 \mathrm{uM}$ pore size nitrocellulose membrane (Amersham, 10600002). The primary antibodies used were NAGK (Proteintech, 15051-1-AP), AKT phosphoS473 (Cell Signaling Technology, 4060), and Vinculin (Sigma, V9264). Membranes were developed using the LI-COR Odyssey CLx system.

\section{RT-qPCR}

For RNA extraction from cells, cells were put on ice, washed with PBS, and scraped into PBS. Samples were then spun down at $200 \mathrm{~g}$ for 5 minutes and resuspended in $100 \mu \mathrm{L}$ Trizol (Life Technologies). For RNA extraction from tissue, samples were resuspended in $500 \mu \mathrm{L}$ Trizol and homogenized using a Tissuelyser twice for $30 \mathrm{~s}$ at $20 \mathrm{~Hz}$. For both cells and tissue, RNA was extracted following the Trizol manufacturer protocol. cDNA was prepared using high-capacity RNA-to-cDNA master mix (Applied Biosystems, 4368814) according to kit instructions. cDNA was diluted 1:20 and amplified with PowerUp SYBR Green Master Mix (Applied Biosystems, A25778) using a ViiA-7 Real-Time PCR system. Fold change in expression was calculated by the $\Delta \Delta \mathrm{C}_{\mathrm{t}}$ method using HPRT as a control. Please see table at end of chapter for primer sequences.

\section{Lectin binding assay}

This manuscript has been co-submitted with Kim et al. (2020), "Pancreatic Cancers Scavenge Hyaluronic Acid to Support Growth." 
Cells were put on ice, washed with PBS and then scraped into PBS. Samples were then spun down at $200 \mathrm{~g}$ for 5 minutes and resuspended in $3 \%$ BSA with fluorophore-conjugated lectin added 1:1000 (Vector Labs FL-1111-2). Samples were covered and incubated on ice for 30 minutes at room temperature, then spun down and resuspended in PBS before analysis with an Attune NxT Flow Cytometer (Thermo Fisher Scientific). Data was further analyzed using FlowJo 8.7.

For all metabolite quantitation experiments, each sample was collected from a $10 \mathrm{~cm}$ subconfluent plate of cells. To achieve similar confluency and protein content at the experiment endpoint, cells were initially plated more densely for the nutrient deprived samples than for the nutrient replete samples. For low glutamine experiments, PANC-1 cells were plated $3 \times 10^{5}$ for 4 $\mathrm{mM}$ glutamine samples and $5.5 \times 10^{5}$ for $0.05 \mathrm{mM}$ samples. MIA PaCa-2 cells were plated $3 \times 10^{5}$ for $4 \mathrm{mM}$ samples and $1.2 \times 10^{6}$ for $0.05 \mathrm{mM}$ samples.

Samples were prepared according to Guo et al. (Guo et al., 2016). Briefly, cells were put on ice and washed $3 x$ with PBS. Then, $1 \mathrm{~mL}$ of ice cold $80 \%$ methanol was added to the plate, and cells were scraped into solvent and transferred to a $1.5 \mathrm{~mL}$ tube. For quantitation experiments, internal standard containing a mix of ${ }^{13} \mathrm{C}$ labeled metabolites was added at this time. Samples were then sonicated and spun down, and the supernatants were dried down under nitrogen. The dried samples were then resuspended in $100 \mu \mathrm{L}$ of $5 \%$ sulfosalicylic acid and analyzed by 164 liquid chromatography-high resolution mass spectrometry as reported (Guo et al., 2016) with the only modification that the LC was coupled to a $\mathrm{Q}$ Exactive-HF with a heated ESI source operating in negative ion mode alternating full scan and MS/MS modes. The $[\mathrm{M}-\mathrm{H}]^{-}$ion of each

167 analyte and its internal standard was quantified, with peak confirmation by MS/MS. GIcNAc This manuscript has been co-submitted with Kim et al. (2020), "Pancreatic Cancers Scavenge Hyaluronic Acid to Support Growth." 
quantification was done on a triple quadropole instrument exactly as described (Guo et al., 2016). Data analysis was conducted in Thermo XCalibur 3.0 Quan Browser and FluxFix (Trefely et al., 2016). For quantitation experiments, samples were normalized first to peak integrations of ${ }^{13} \mathrm{C}$-labeled internal standard components and then to protein content in the sample, measured by BCA assay. Relative quantification was then calculated by normalizing to the control condition in each experiment.

For glucose labeling experiments, cells were cultured in DMEM without glucose, glutamine, or phenol red supplemented with $10 \mathrm{mM}\left[\mathrm{U}-{ }^{13} \mathrm{C}\right]$-glucose (Cambridge Isotopes, CLM-1396-1), 4 $\mathrm{mM}$ glutamine, and $10 \%$ dialyzed fetal bovine serum. Cells were incubated for the indicated time, and samples were prepared as above. For GlcNAc labeling experiments, cells were cultured in DMEM without glucose, glutamine, or phenol red supplemented with $10 \mathrm{mM} \mathrm{N}-[1,2-$ 13C2]acetyl-D-glucosamine $\left({ }^{13} \mathrm{C}\right.$ GlcNAc) (Omicron Biochemicals, GLC-006), 4 mM glutamine, $10 \mathrm{mM}$ glucose, and $10 \%$ dialyzed fetal bovine serum. Cells were incubated for the indicated time, and samples were prepared as above.

\section{Soft agar colony formation assay}

Cells were trypsinized and counted using a Bright-Line hemacytometer (Sigma, Z359629). The bottom agar layer was prepared by adding Bacto Agar (BD Bioscience, 214050) to cell culture media for a final concentration of $0.6 \% .2 \mathrm{~mL}$ bottom agar was added to each well of a 6 -well tissue culture plate. Once bottom agar solidified, top layer agar was prepared by combining trypsinized cells with the bottom agar mix for a final concentration of $0.3 \%$ Bacto Agar. $1 \mathrm{~mL}$ top layer agar was added to each well with a bottom layer of agar. Cells were plated $2.5 \times 10^{4}$ per well. $0.5 \mathrm{~mL}$ DMEM high glucose with $10 \%$ calf serum was added to cells every 7 days. Images

This manuscript has been co-submitted with Kim et al. (2020), "Pancreatic Cancers Scavenge Hyaluronic Acid to Support Growth." 
were taken after 3 weeks. Images were blinded and colonies per image were counted using

191 ImageJ (Schneider et al., 2012).

\section{D Proliferation assay}

193 Cells were plated $3.5 \times 10^{4}$ per well of a 6 -well plate. For each day that counts were recorded, 194 three wells were trypsinized and cells were counted twice using a hemocytometer (Sigma, 195 Z359629). The average of the two counts was recorded for each well, and the average count of 196 the three wells was used to graph the data. For proliferation assays in $0.05 \mathrm{mM}$ glutamine, 197 trypan blue was used during cell counts.

\section{Bioinformatics data analysis}

The PDAC expression profiling dataset (GEO accession GSE16515, Pei et al., 2009) from NCBI GEO Profile database (Edgar et al., 2002) was used to compare the expression level between human normal and PDAC tumor samples. The dataset consists of 52 samples, in which 16 samples are matched tumor and normal tissues, and 20 samples are only tumor tissues. The

203 statistical analysis was conducted by one-way ANOVA, the level of significance was evaluated

204 by $p<0.01$ and plotted in box-and-whisker diagram. Comparison of HBP gene expression 205 between tumor (TCGA PAAD dataset) and normal tissue (GTEx) was also conducted using 206 GEPIA2 (Tang et al., 2019).

\section{Tumor growth in vivo}

3x106 PANC-1 NAGK CRISPR cells were injected with 1:1 Matrigel (Corning, CB354248) into

209 the flanks of $\mathrm{NCr}$ nude mice and measured with calipers once per week for 22 weeks. At the experiment endpoint (22 weeks or when tumor reached $20 \mathrm{~mm}$ in length), mice were euthanized

211 with $\mathrm{CO}_{2}$ and cervical dislocation. Tumors were removed, weighed, cut into pieces for analysis, This manuscript has been co-submitted with Kim et al. (2020), "Pancreatic Cancers Scavenge Hyaluronic Acid to Support Growth." 
212 and frozen. All animal experiments were approved by the University of Pennsylvania and the

213 Institutional Animal Care and Use Committee (IACUC).

Results

\section{Tetra-antennary N-glycans and O-GIcNAcylation are minimally impacted by nutrient limitation in pancreatic cancer cells}

219 To examine the effects of nutrient deprivation on glycosylation, we cultured cells under 220 glucose or glutamine limitation and examined O-GlcNAc levels and cell surface 221 phytohemagglutinin-L (L-PHA) binding, a readout of $\mathrm{N}$-acetylglucosaminyltransferase 5 222 (MGAT5)-mediated cell surface N-glycans (Fig S1A, B), which are highly sensitive to UDP223 GlcNAc availability (Lau et al., 2007). We focused on glucose and glutamine because of their 224 requirement to initiate the HBP (Fig. 1A). First, as a positive control, we examined HCT-116 and 225 SW480 colon cancer cells, previously documented to have glucose-responsive O-GlcNAcylation 226 (Park et al., 2010; Steenackers et al., 2016), which we also confirmed in HCT-116 cells (Fig. 227 1B). Indeed, L-PHA binding was suppressed by glucose restriction in SW480 cells and by 228 glutamine restriction in both colon cancer cell lines (Fig. 1C). Next, to test whether glycans were 229 sensitive to nutrient restriction in PDA cells, we examined L-PHA binding and O-GIcNAc levels 230 under nutrient deprivation conditions in a panel of human PDA cell lines, including PANC-1, MIA

231 PaCa-2, AsPC-1, and HPAC. Across these cell lines, no consistent changes in L-PHA binding 232 were observed under glucose or glutamine limitation (Fig. 1D, E; Fig. S1C). We also examined 233 L-PHA binding in PDA cells under oxygen- or serum-deprived conditions and observed minimal 234 changes (Figure S1D, E). O-GlcNAcylation was minimally altered by culture in low glutamine 235 and exhibited variable changes in response to glucose limitation (Fig. 1F), consistent with 
bioRxiv preprint doi: https://doi.org/10.1101/2020.09.13.294116; this version posted June 21, 2021. The copyright holder for this preprint (which was not certified by peer review) is the author/funder. All rights reserved. No reuse allowed without permission.

A

Hexosamine Biosynthesis Pathway (HBP)

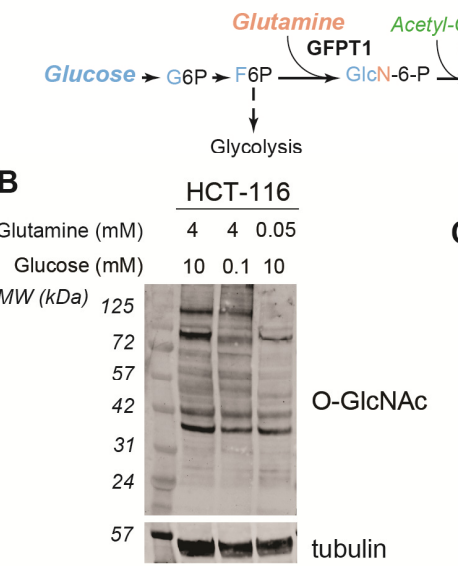

C

UTP SPGM UAP1

D
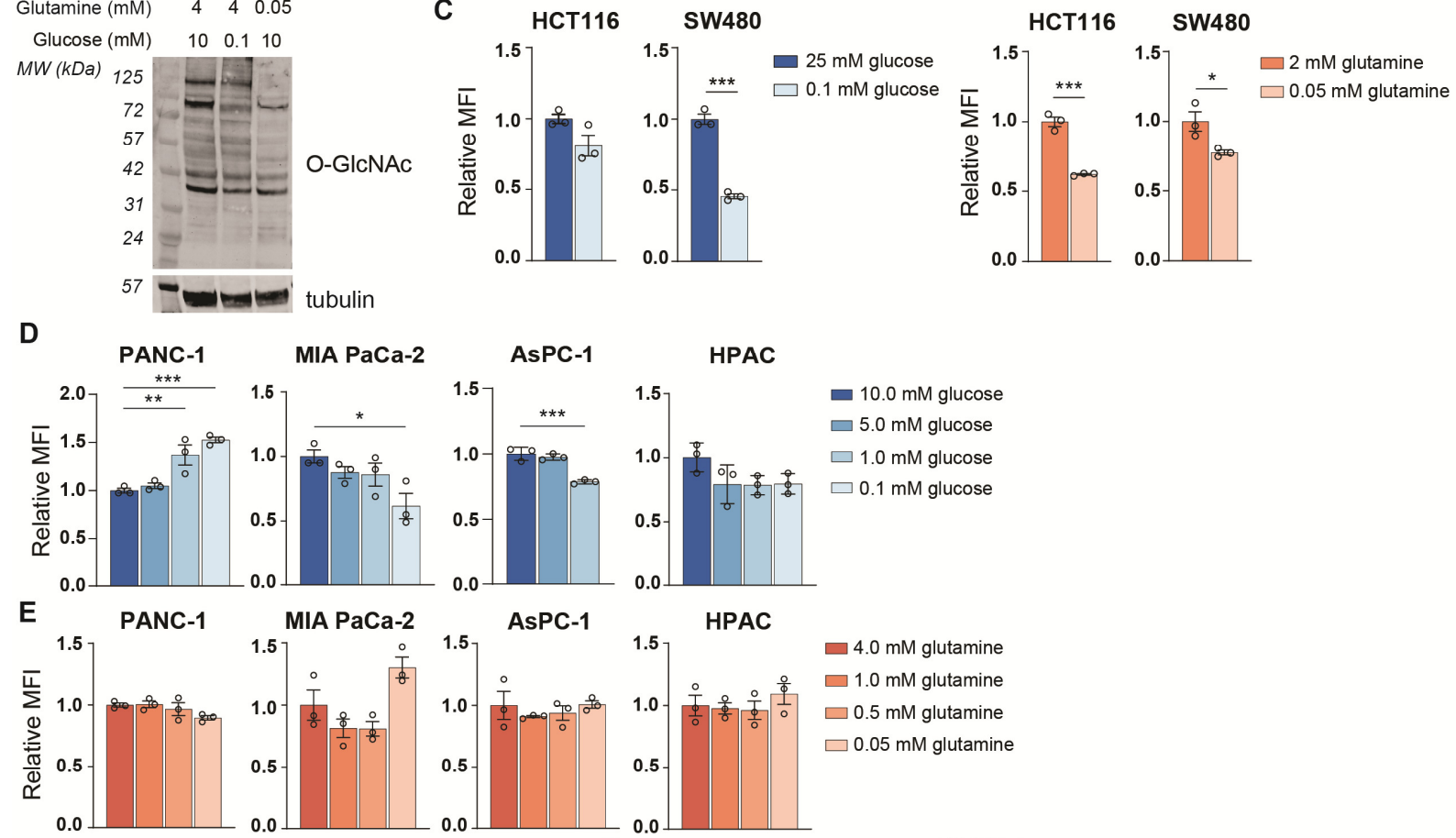

MIA PaCa-2
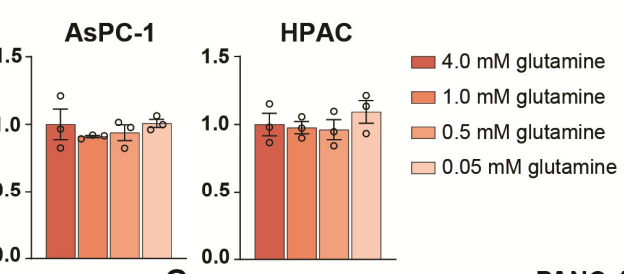

$\mathbf{F}$

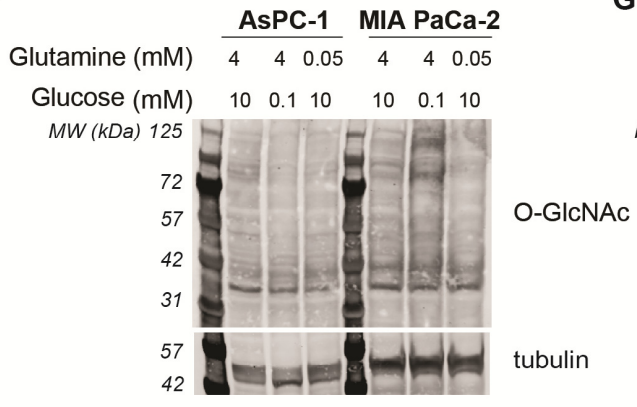

G

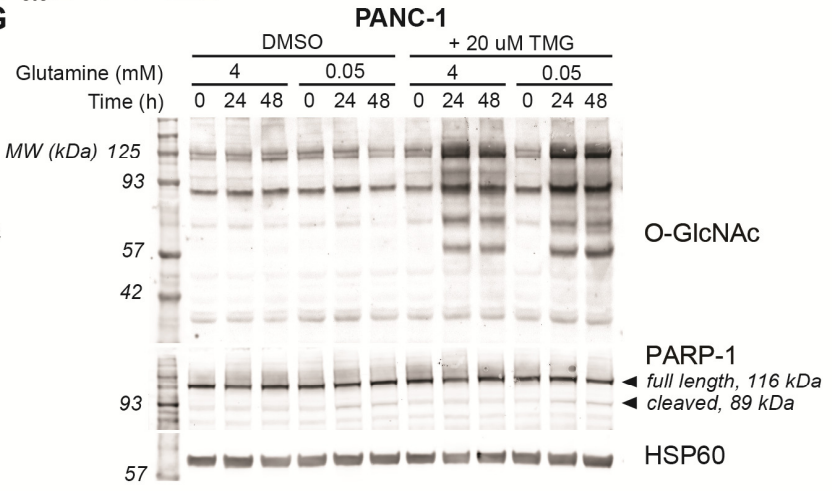

Figure 1: MGAT5-dependent $\mathrm{N}$-glycans are minimally impacted by glucose or glutamine deprivation in PDA cells.

A) Overview of the hexosamine biosynthesis pathway (HBP). B) O-GlcNAc levels in HCT-116 cells in high and low nutrients; cells were incubated in indicated concentrations of glucose and glutamine for 48 hours. C) Phytohemagglutinin-L (LPHA) binding in colon cancer cells. Cells were incubated in the indicated concentrations of glucose (left) or glutamine (right) for 48 hours and then analyzed by flow cytometry. Graph shows mean fluorescence intensity (MFI) relative to control condition. Statistical significance was calculated by unpaired t-test. D-E) Phytohemagglutinin-L (LPHA) binding in pancreatic ductal adenocarcinoma (PDA) cells in low nutrients. Cells were incubated in the indicated concentrations of glucose (D) or glutamine (E) for 48 hours and then analyzed by flow cytometry. Statistical significance was calculated by one-way ANOVA. F) O-GIcNAc levels in PDA cells in high and low nutrients. Cells were incubated in the indicated concentrations of glucose or glutamine for 48 hours. G) Western blot for O-GlcNAc and PARP in PANC-1 cells cultured in the indicated concentrations of glutamine with or without Thiamet-G (TMG) treatment for the indicated time. For all bar graphs, mean $+/$ - standard error of the mean (SEM) of three biological triplicates is represented. Panels B) - G) are representative of at least two independent

experimental replicates. ${ }^{*}, p \leq 0.05 ;{ }^{* *}, p \leq 0.01 ;{ }^{* *}, p \leq 0.001$.

This manuscript has been co-submitted with Kim et al. (2020), "Pancreatic Cancers Scavenge Hyaluronic Acid to Support Growth." 
stress-induced regulation of this modification (Taylor et al., 2008). Since glycosylation may be maintained through either sustained ability to add the modifications or through changes in turnover, we assayed active O-GIcNAcylation by inhibiting O-GIcNAcase with Thiamet G (TMG). TMG treatment resulted in equivalently elevated O-GlcNAcylation levels in high and low glutamine conditions (Fig. 1G; Fig. S1F), indicating that glutamine restriction does not limit the capacity of cells to add the O-GIcNAc modification. Mia-PaCa-2 cells exhibited some cell death

245 in low glutamine, though this was not exacerbated by TMG treatment (Fig. S1F). Thus, under a 246 variety of nutrient stress conditions, neither L-PHA binding nor O-GlcNAcylation were consistently suppressed in pancreatic cancer cell lines. Glutamine restriction in particular had remarkably little impact on O-GIcNAcylation and L-PHA binding, raising the question of how UDP-GlcNAc is generated during nutrient limitation.

\section{De novo UDP-GICNAc synthesis is suppressed upon glutamine limitation}

252 We therefore next asked whether the abundance of HBP metabolites is impacted by nutrient limitation. We measured HBP metabolites after glucose or glutamine restriction using HPLC-MS

254 (Guo et al., 2016). In low glutamine conditions, GlcN-6-P levels were potently decreased relative (Fig. 2A). In MIA PaCa-2 cells, UDP-GIcNAc abundance actually increased upon glutamine restriction (Fig S2.1A). These data indicate that UDP-GlcNAc might be generated through mechanisms other than de novo synthesis. Glycolytic intermediates were minimally impacted by

259 low glutamine conditions, and TCA cycle intermediates such as $\alpha-K G$ and malate decreased as 260 expected (Fig. 2A, Fig. S2.1A). In contrast to that in glutamine restriction, UDP-GIcNAc abundance declined in $5 \mathrm{mM}$ or $0.1 \mathrm{mM}$ relative to $10 \mathrm{mM}$ glucose conditions (Fig. S2.1B), 
bioRxiv preprint doi: https://doi.org/10.1101/2020.09.13.294116; this version posted June 21, 2021. The copyright holder for this preprint (which was not certified by peer review) is the author/funder. All rights reserved. No reuse allowed without permission.
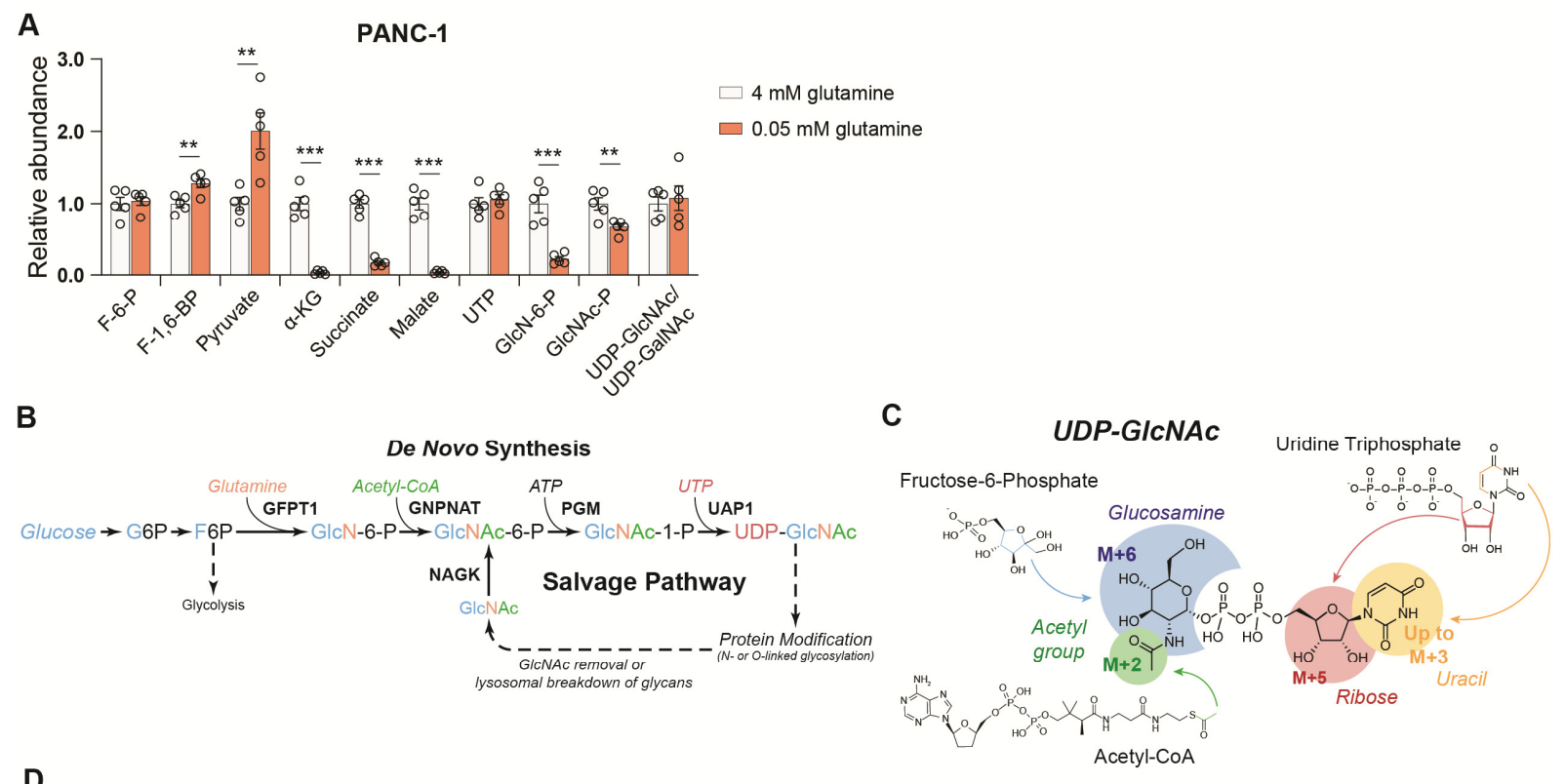

\section{D}
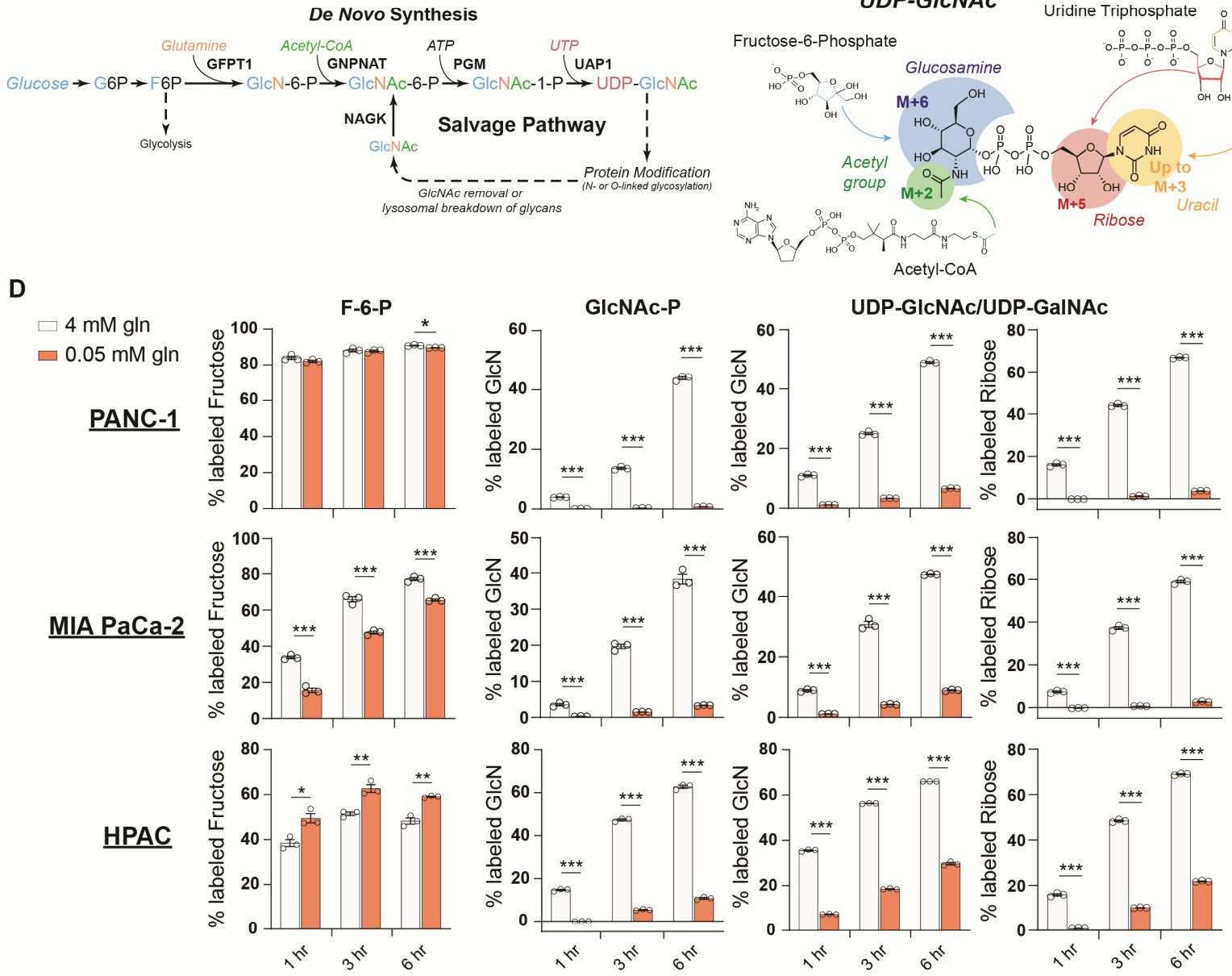

Figure 2: De novo UDP-GICNAc synthesis is supressed upon glutamine limitation.
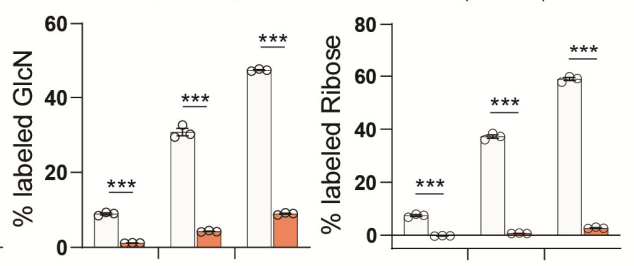

A) Metabolite measurements in PANC-1 and MIA PaCa-2 cells after culture for 48 hours in $0.05 \mathrm{mM}$ glutamine. Quantification is normalized to $4 \mathrm{mM}$ glutamine condition. Statistical significance was calculated by unpaired t-test.Mean +/- SEM is represented. B) Overview of the GIcNAc salvage pathway feeding into the HBP. GIcNAc scavenged from O-GIcNAc removal or lysosomal breakdown of glycans can be phosphorylated by NAGK and used to regenerate UDP-GICNAC. C) Overview of the incorporation of ${ }^{13} \mathrm{C}$ glucose into UDP-GICNAc. Different parts of the molecule can be labeled from glucose-derived subunits, thus isotopologues up to $\mathrm{M}+16$ can be derived from glucose. D) ${ }^{13} \mathrm{C}$ glucose tracing into F-6-P, GlcNAc-P, and UDP-GlcNAc in indicated glutamine concentrations. \% labeled $\mathrm{GlcN}$ indicates sum of $\mathrm{M}+6$ and $\mathrm{M}+8$ isotopologues for GlcNAc-P and sum of $\mathrm{M}+6, \mathrm{M}+8, \mathrm{M}+11$, and $\mathrm{M}+13$ for UDP-GlcNAc, \% labeled Ribose indicates sum of $\mathrm{M}+5, \mathrm{M}+7, \mathrm{M}+11$, and $\mathrm{M}+13$ for UDP-GIcNAc. All isotopologues are graphed in Figure $\mathrm{S} 2$. Statistical significance was calculated by unpaired t-test. Mean $+/$ - SEM is represented. ${ }^{*}, p \leq 0.05 ;{ }^{* *}, p \leq 0.01 ;{ }^{* * *}, p \leq 0.001$. 
suggesting that glutamine limitation specifically may trigger an adaptive response to sustain UDP-GIcNAc pools.

We sought to understand how UDP-GIcNAc pools are sustained during glutamine restriction. regenerate UDP-GIcNAc (Fig. 2B). However, NAGK's roles in physiology and cancer biology

271 have been minimally studied. To investigate the possibility that UDP-GlcNAc is generated 272 through mechanisms other than its synthesis from glucose, we first designed a stable isotope 273 labeling strategy to quantify the fraction of the glucosamine ring that is synthesized de novo in 274 glutamine-replete versus -restricted conditions. Since multiple components of UDP-GlcNAc 275 [glucosamine ring, acetyl group, uridine (both the uracil nucleobase and the ribose ring)] can be 276 synthesized from glucose, UDP-GIcNAc isotopologues up to $M+16$ can be generated from 277 glucose (Moseley et al., 2011) (Fig. 2C). In order to measure the glucose carbon incorporated 278 into GICNAc-P and UDP-GICNAc via the HBP, all isotopologues containing a fully labeled 279 glucosamine ring are added together ( $\%$ labeled GlcN indicates sum of $M+6, M+8, M+11$, and 280 $\mathrm{M}+13$ for UDP-GIcNAc and sum of $\mathrm{M}+6$ and $\mathrm{M}+8$ for GlcNAc-P) (Fig. 2C).

After 48 hours of glutamine restriction, cells were incubated with fresh low glutamine medium 282 containing $\left[\mathrm{U}-{ }^{13} \mathrm{C}\right]$-glucose to track the incorporation of glucose carbons into hexosamine 283 intermediates. Across multiple PDA cell lines, the fractional labeling of the glucosamine ring in 284 both GICNAc-P and UDP-GIcNAc pools was markedly suppressed by glutamine restriction, 285 indicating decreased de novo synthesis in low glutamine conditions (Fig. 2D, Fig. S2.1C-E). 286 Notably, labeling into the ribose component of UDP-GIcNAc was also suppressed [\% labeled 287 ribose indicates sum of isotopologues containing $M+5$ (i.e., $M+5, M+7, M+11$, and $M+13$ ); Fig. This manuscript has been co-submitted with Kim et al. (2020), "Pancreatic Cancers Scavenge Hyaluronic Acid to Support Growth." 
2D, Fig. S2.1C]. Consistently, incorporation of ${ }^{13} \mathrm{C}$ glucose into uridine triphosphate (UTP) was suppressed upon glutamine restriction (Fig. S2.2A), even though UTP levels were maintained or increased (Fig. 2A, Fig. S2.1A), suggesting a role for nucleoside salvage in maintaining nucleotide pool in these conditions. This is consistent with previous reports demonstrating that autophagy/ ribophagy is a source of nucleosides in amino acid deprived conditions (Guo et al., 2011; Wyant et al., 2018). Indeed, silencing of either of the uridine salvage enzymes uridine

294 kinase 1 or 2 (UCK1/2) resulted in decreased UDP, UTP, and UDP-GlcNAc levels (Fig. S2.2B-

295 C), indicating that nucleoside salvage contributes to maintaining uridine phosphate and UDP-

296 GlcNAc pools. Thus, glutamine restriction suppresses the de novo synthesis of both GlcNAc-P and UTP, both of which are required to produce UDP-GIcNAc.

We noted that GIcNAc-P and UDP-GIcNAc pools labeled from glucose with similar but not identical kinetics. While this is potentially due to limitations in detection since GlcNAc-P is much less abundant than UDP-GIcNAc, we considered whether GlcNAc-P-independent pathways may also have minor contributions to glucose-dependent UDP-GlcNAc labeling. Although pathways through which glucose can feed into UDP-GlcNAc's glucosamine ring independent of the HBP have not been described in mammalian cells to our knowledge, we nevertheless tested 304 the two major metabolic branch points diverging from UDP-GlcNAc, which mediate UDP305 GalNAc and sialic acid synthesis. UDP-galactose-4-epimerase (GALE) interconverts UDPGIcNAc and UDP-GalNAc, and UDP-GlcNAc-2-epimerase/ManAc kinase (GNE) initiates sialic 307 acid biosynthesis. Silencing of neither GALE nor GNE reduced UDP-GlcNAc labeling from 308 glucose, however, indicating that these enzymes are unlikely to facilitate a bypass pathway (Fig. S2.2D-E). Although a minor contribution from another unknown pathway cannot be ruled out, the slight apparent differences in timing of GIcNAc-P and UDP-GIcNAc labeling most likely 
311 reflect technical limitations. Regardless, the data clearly indicate that UDP-GIcNAc abundance

312 is maintained despite reduced de novo hexosamine synthesis from glucose (Fig. 2D).

\section{GIcNAc salvage feeds UDP-GIcNAc pools in pancreatic cancer cells}

As mentioned, UDP-GlcNAc can be generated via phosphorylation of free GlcNAc by NAGK generating GlcNAc-6-P (Fig. 2B). When supplemented, GlcNAc is salvaged into the UDPGlcNAc pool (Ryczko et al., 2016; Wellen et al., 2010). Endogenous sources of GlcNAc may include removal of O-GIcNAc protein modifications or breakdown of glycoconjugates and extracellular matrix components. Notably, intracellular levels of GlcNAc increase upon glutamine restriction (Fig. 3A). Yet, the significance of GlcNAc salvage to maintenance of UDP-GIcNAc pools has been little studied, and the proportion of UDP-GICNAc generated via the NAGKdependent salvage pathway is unknown. cell lines also in low glucose (Fig. S2.3A, B). GFPT1 expression was also induced in both low

324 glucose conditions, consistent with a prior report (Moloughney et al., 2016), and in low 325 glutamine conditions (Fig. S2.3A), even though de novo synthesis is suppressed when 326 glutamine is limited. Protein levels of NAGK did not increase in concordance with mRNA at 327 these time points, however, although a mobility shift potentially indicative of post-translational 328 modification was apparent when protein lysates were run on a gel using a large electrophoresis 329 system (see methods; Fig S2.3C-D). Removal of the phosphatase inhibitor $\mathrm{Na}_{3} \mathrm{VO}_{4}$ from the 330 sample buffer prevented the mobility shift, suggesting that NAGK may be phosphorylated on 331 one or more residues in low glutamine conditions (Fig. S2.3D). Taken together, these data 332 indicate that under low glutamine conditions, GIcNAc availability for salvage increases and the 333 salvage enzyme NAGK is subject to regulation.

334 This manuscript has been co-submitted with Kim et al. (2020), "Pancreatic Cancers Scavenge Hyaluronic Acid to Support Growth." 
bioRxiv preprint doi: https://doi.org/10.1101/2020.09.13.294116; this version posted June 21, 2021. The copyright holder for this preprint (which was not certified by peer review) is the author/funder. All rights reserved. No reuse allowed without permission.

A

\section{GIcNAc}

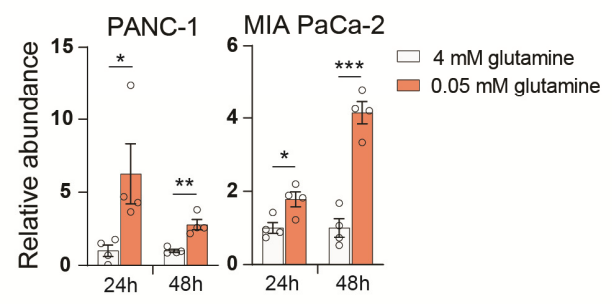

B

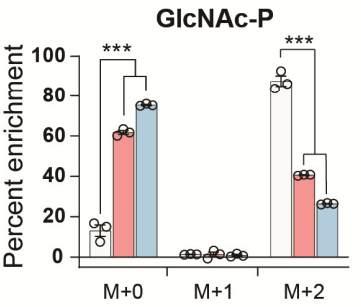

UDP-GIcNAc/UDP-GaINAc

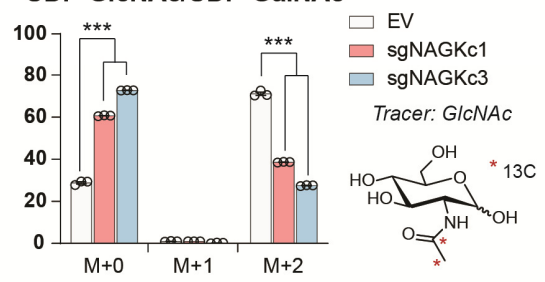

MIA PaCa-2

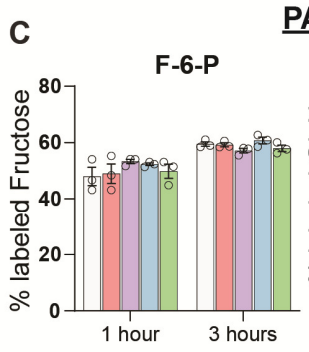

PANC-1
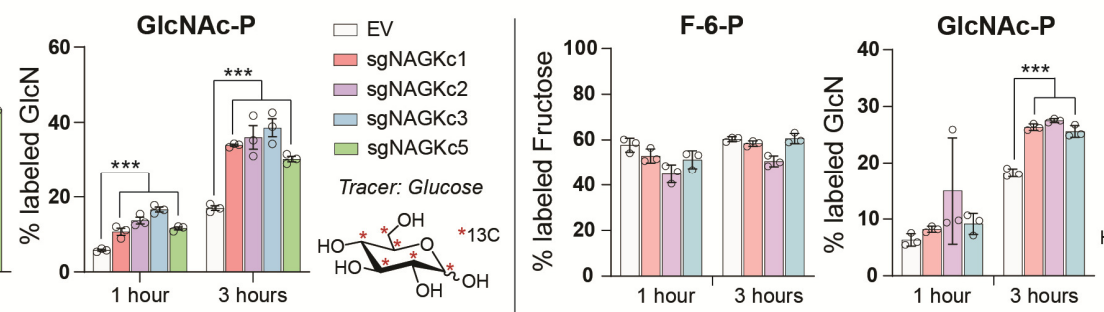

$\square \mathrm{EV}$

$\square$ sgNAGK 1

$\square$ sgNAGK c2

$\square$ sgNAGK c3

Tracer: Glucose

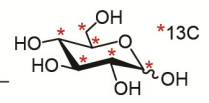

UDP-GIcNAc/UDP-GaINAc

\section{UDP-GICNAC/UDP-GaINAc}
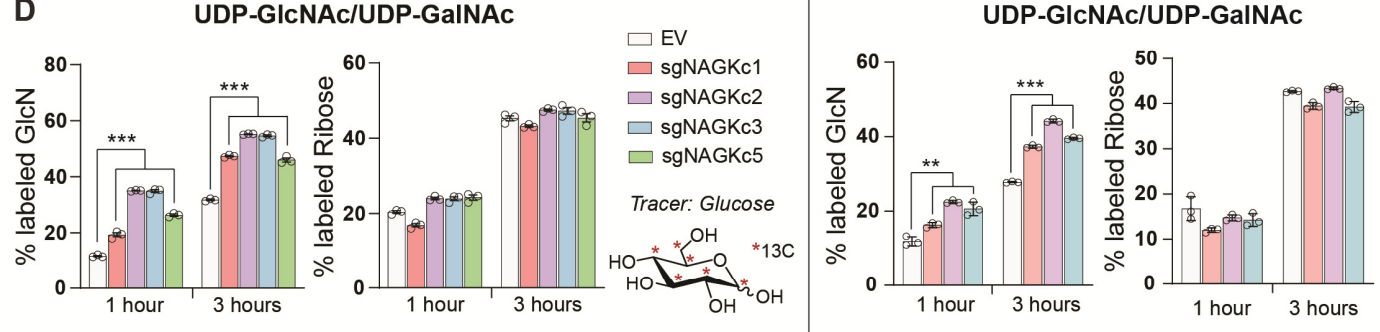

$\square \mathrm{EV}$

$\square$ sgNAGK c1

$\square$ sgNAGK c2

$\square$ sgNAGK c3

Tracer: Glucose

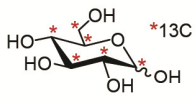

E

F-6-P

GICN-P

GICNAC-P

UDP-GICNAC/ UDP-GaINAC

GIcNAc
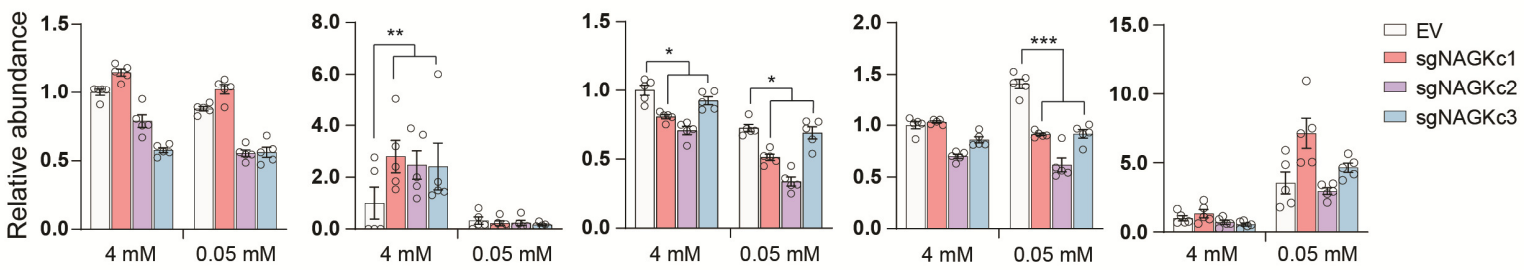

Figure 3: GIcNAc salvage feeds UDP-GIcNAc pools in pancreatic cancer cells.

A) Measurement of GICNAc in PANC-1 and MIA PaCa-2 cells after incubation in the indicated concentrations of glutamine for 24 and 48 hours. Mean + - SEM of four biological replicates is represented. Statistical significance was calculated by unpaired t-test. B) Measurement of $13 \mathrm{C}$ GlcNAc labeled on the acetyl group into GIcNAc-P and UDP-GIcNAc in NAGK knockout cells. Cells were incubated with $10 \mathrm{mM} 13 \mathrm{C}$ GlcNAc for 6 hours. Mean +/SEM of three biological replicates is represented. Statistical significance was calculated by unpaired t-test comparing the mean incorporation of the two CRISPR clones and the empty vector (EV) control. C) Labeling of F-6-P and GIcNAc-P from 13C glucose in PANC-1 (left) and MIA PaCa-2 (right) NAGK knockout cells. Statistical significance was calculated by unpaired t-test comparing the mean incorporation of the four CRISPR clones and the EV control. Mean +/- SEM of three biological replicates is represented. D) Percent of combined UDP-GlcNAc isotopologues containing a labeled glucosamine ring or a labeled ribose from UTP, calculated from S3.1 (E). Statistical significance was calculated by unpaired t-test comparing the mean incorporation of the four CRISPR clones and the EV control. Mean +/- SEM of three biological replicates is represented. E) Measurement of HBP metabolites in PANC-1 NAGK knockout cells cultured in the indicated concentrations of glutamine. Statistical significance was calculated by unpaired t-test comparing the mean incorporation of the four CRISPR clones and the EV control. Mean $+/-$ SEM of four biological replicates is represented. *, $\mathrm{p} \leq 0.05 ;{ }^{* *}, \mathrm{p} \leq 0.01 ;{ }^{* * *}, \mathrm{p} \leq 0.01$. 
These findings prompted us to investigate the role of NAGK in UDP-GIcNAc synthesis in PDA cells. We functionally examined the role of NAGK in PDA cell lines by using CRISPR-Cas9 gene editing to generate NAGK knockout (KO) PANC-1 and MiaPaCa-2 clonal cell lines (Fig. S3.1AB). $\mathrm{N}-\left[1,2-{ }^{13} \mathrm{C}_{2}\right]$ acetyl-D-glucosamine $\left({ }^{13} \mathrm{C}\right.$ GlcNAc) was efficiently salvaged in control cells, and 341 this was suppressed by NAGK deletion, as evidenced by reduced fractional labeling of GIcNAc$342 \mathrm{P}$ and UDP-GICNAc (Fig. 3B). Since we did not observe any residual protein expression, we 343 hypothesized that the N-acetylgalactosamine (GalNAc) salvage enzyme GalNAc kinase 344 (GALK2) might be responsible for the remaining GlcNAc salvage in the absence of NAGK. 345 Indeed, silencing of GALK2 further suppressed incorporation of ${ }^{13} \mathrm{C}$ GlcNAc into GlcNAc-P and 346 UDP-GIcNAc in the NAGK KO cells (Fig. S3.1C).

We hypothesized that knockout cells would conversely conduct increased de novo UDPGlcNAc synthesis. To test this, we incubated cells with $\left[\mathrm{U}-{ }^{13} \mathrm{C}\right]$-glucose and examined 349 incorporation into GlcNAc-P and UDP-GIcNAc. Indeed, in the absence of NAGK, we observed 350 increased glucose-dependent fractional labeling of the glucosamine ring of UDP-GIcNAc and 351 GlcNAc-P, but not the ribose component of UDP-GlcNAc (Fig. 3C-D; Fig. S3.1D-E). This effect 352 was also observed with knockdown of NAGK by shRNA, though to a lesser extent (Fig. S3.2AB). Incorporation of glucose into F-6-P did not change (Fig. 3C) and the proportion of UDP354 GlcNAc containing an M+5 ribose ring was also unchanged in knockout cells (Fig. 3D), as expected. Thus, when NAGK is deleted and GlcNAc salvage is suppressed, de novo hexosamine synthesis increases.

357 We next assessed changes in the levels of hexosamine intermediates in control and NAGK $358 \mathrm{KO}$ cell lines. In PANC-1 KO cells in 4 mM glutamine, GlcN-P increased significantly, consistent 359 with increased de novo synthesis in the absence of NAGK (Fig. 3E). GIcNAc-P was modestly This manuscript has been co-submitted with Kim et al. (2020), "Pancreatic Cancers Scavenge Hyaluronic Acid to Support Growth." 
reduced in KO cells, though UDP-GIcNAc levels were maintained (Fig. 3E). In MIA PaCa-2 cells, GIcNAc-P was markedly suppressed in the absence of NAGK, though UDP-GIcNAc was not (Fig. S3.2C). We also measured HBP metabolites under glutamine restriction, where we expected NAGK would play a more significant role in UDP-GICNAc generation. We were only able to measure metabolites accurately in PANC-1 KO cells because MIA PaCa-2 NAGK KO cells began to die quickly in low glutamine, which will be discussed further in the next section. GlcN-P decreased in control and KO cells, consistent with reduced de novo hexosamine synthesis (Fig. 3E). GlcNAc-P levels decreased in low glutamine in control cells, and decreased further in cells lacking NAGK, consistent with contributions from both de novo synthesis and salvage (Fig. 3E). Reciprocally, GIcNAc abundance was elevated upon glutamine limitation in both control and NAGK KO cells (Fig. 3E). UDP-GICNAc abundance was modestly reduced in NAGK KO cells relative to controls under glutamine restriction, though levels were still comparable to that in high glutamine (Fig. 3E), possibly reflecting changes in utilization. GALK2 silencing did not further suppress UDP-GIcNAc in NAGK KO cells (Fig. S3.2D), suggesting that GALK2 may not have a major role in physiological GIcNAc salvage. Cumulatively, the data demonstrate that GIcNAc is salvaged into UDP-GIcNAc pools in PDA cells in a manner dependent at least in part on NAGK.

\section{NAGK knockout limits tumor growth in vivo}

To test the role of NAGK in cell proliferation, we first monitored growth of NAGK KO cells compared to controls in 2D and 3D culture in $4 \mathrm{mM}$ glutamine, finding minimal differences (Fig. 4A, Fig. S4A). We hypothesized that NAGK KO cell proliferation would be impaired in $0.05 \mathrm{mM}$

This manuscript has been co-submitted with Kim et al. (2020), "Pancreatic Cancers Scavenge Hyaluronic Acid to Support Growth." 
bioRxiv preprint doi: https://doi.org/10.1101/2020.09.13.294116; this version posted June 21, 2021. The copyright holder for this preprint (which was not certified by peer review) is the author/funder. All rights reserved. No reuse allowed without permission.

A

PANC-1
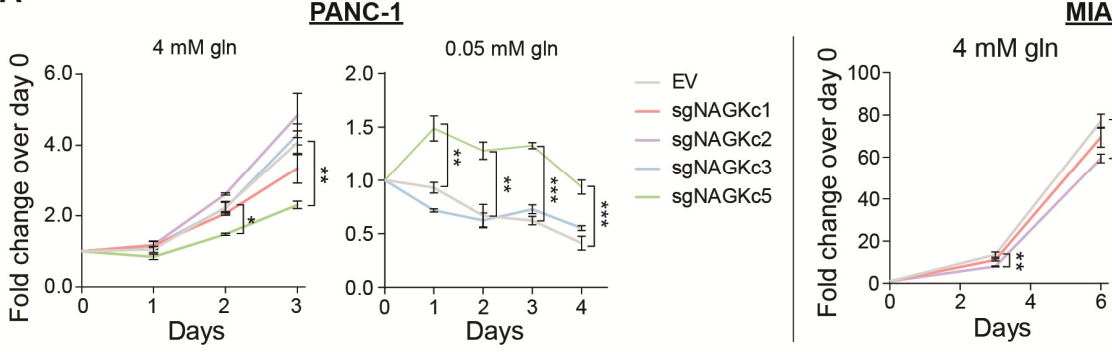

MIA PaCa-2
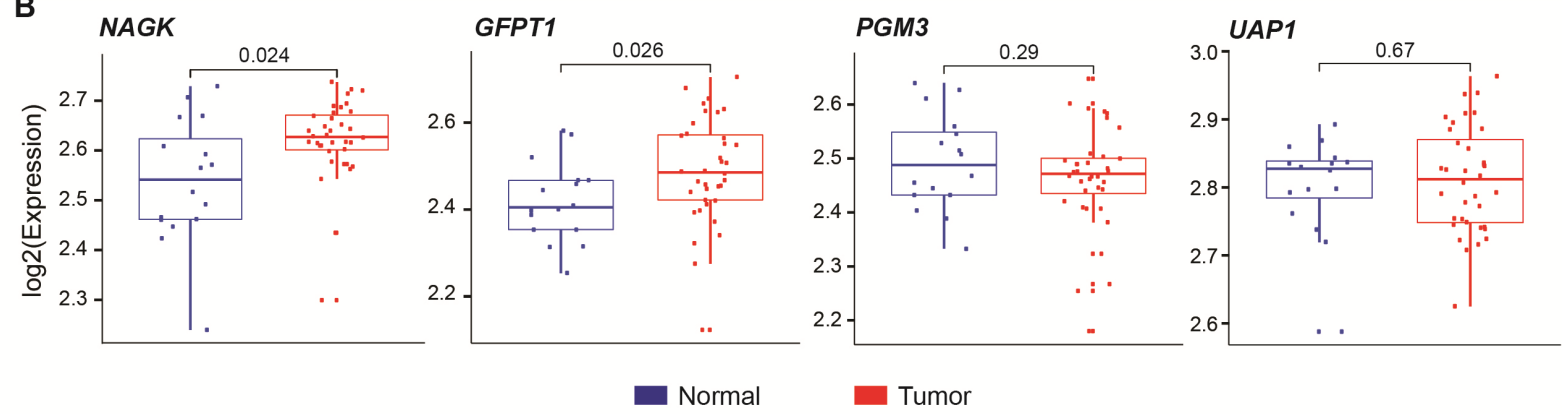

C Final tumor volume

D Final tumor weight
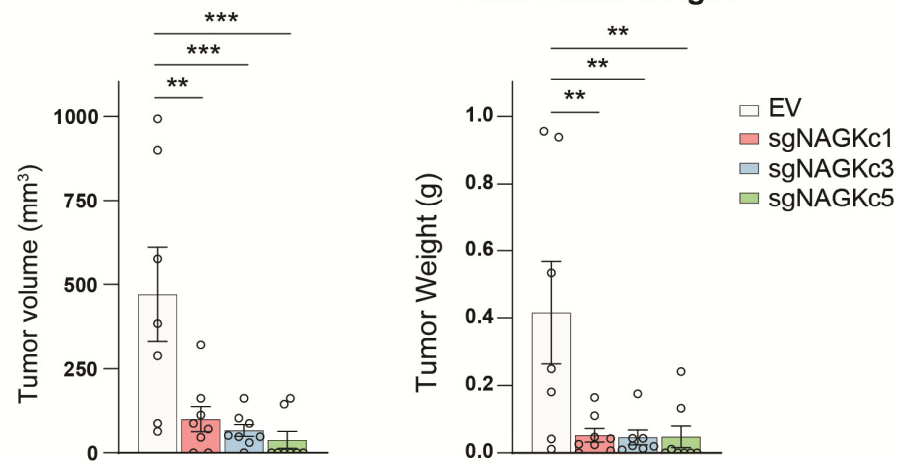

Figure 4: NAGK expression is increased in human PDA tumors and NAGK knockout reduces tumor growth in vivo.

A) 2D proliferation assay by cell count in PANC-1 and MIA PaCa-2 NAGK knockout cells. Mean +/- SEM of three technical replicates is represented. Statistical significance was calculated using one-way ANOVA at each time point. B) Gene expression data for NAGK, GFPT1, PGM3, and UAP1 in human PDA tumors compared with matched normal tissue. Statistical analysis was conducted by one-way ANOVA, and level of significance was defined as $p \leq 0.01$. C) Final tumor volume and D) final tumor weight of subcutaneous tumors generated from PANC-1 NAGK knockout cells in vivo. Cells were injected into the right flank of $\mathrm{NCr}$ nude mice and tumor volume was calculated from caliper measurements. Statistical significance was calculated by one-way ANOVA comparing each mean to the EV control mean. Mean $+/$ - SEM of biological replicates is represented $(n=8$ each group). ${ }^{*}, p \leq 0.05 ;{ }^{* *}, p \leq 0.01 ; * * *, p \leq 0.001$.

384 This manuscript has been co-submitted with Kim et al. (2020), "Pancreatic Cancers Scavenge Hyaluronic Acid to Support Growth." 
glutamine, where de novo UDP-GIcNAc synthesis is suppressed. Indeed, MIA PaCa-2 KO cells died more quickly in $0.05 \mathrm{mM}$ glutamine than did control cells (Fig. 4A). PANC-1 KO cells did not show this effect (Fig. 4A), but we hypothesized that NAGK loss might have a stronger effect in vivo where tumor growth can be constrained by nutrient availability. in vivo, we queried publicly available datasets. From analysis of publicly available microarray data (Pei et al., 2009) and gene expression data from the Cancer Genome Atlas (TCGA), we indeed found NAGK expression to be increased in tumor tissue relative to adjacent normal regions of the pancreas or to pancreas GTEx data (Fig. 4B, Fig. S4B). GFPT1 expression was also increased in tumor tissue (Fig. 4B, Fig. S4B), consistent with its regulation by mutant KRAS 395 (Ying et al., 2012). Two other HBP genes, PGM3 and UAP1, did not show significantly increased expression in PDA tumors in these datasets (Fig. 4B, Fig. S4B). We then studied the role of NAGK in tumor growth in vivo by injecting NAGK CRISPR KO cells into the flank of $\mathrm{NCr}$ nude mice. Final tumor volume and weight were markedly reduced in the absence of NAGK (Fig. 4C-D). Of note, initial tumor growth was comparable between control and KO cells, but the NAGK knockout tumors either stopped growing or shrank while control tumors continued to 401 grow larger (Fig. S4C). Interestingly, KO tumor samples showed increased L-PHA signal (Fig. 402 S4D), indicating that NAGK deficiency results in altered glycosylation within tumors. This could possibly reflect either elevated de novo synthesis in the small tumors that form or differences in 404 cellular composition. For example, activated fibroblast marker $\alpha$-smooth muscle actin ( $\alpha$-SMA) was more abundant in the NAGK KO tumors (Fig S4D). Residual NAGK signal in whole tumors also presumably reflects expression in other cell types (Fig. S4D), since NAGK was 407 undetectable in the clonal cell lines used for injections (Fig. S3.1B). Taken together, these data This manuscript has been co-submitted with Kim et al. (2020), "Pancreatic Cancers Scavenge Hyaluronic Acid to Support Growth." 
becomes more important as the tumors outgrow their original nutrient supply and become more

410 dependent on scavenging and recycling and indicate that NAGK-mediated hexosamine salvage

411 supports tumor growth in vivo.

\section{DISCUSSION}

414 In this study, we identify a key role for NAGK in salvaging GIcNAc for UDP-GlcNAc synthesis

415 in PDA cells. We show that glutamine deprivation suppresses de novo hexosamine

416 biosynthesis, which is reciprocally increased upon NAGK deletion. Glutamine deprivation also

417 results in increased availability of GlcNAc for salvage. NAGK expression is elevated in human

418 PDA tumors, and NAGK deficiency suppresses GlcNAc salvage in cells and tumor growth in 419 mice.

420 This work raises several key questions for future investigation. First, the sources of GlcNAc 421 salvaged by NAGK remain to be fully elucidated. GlcNAc may be derived from recycling of 422 GlcNAc following O-GlcNAc removal or breakdown of glycoconjugates. Additionally, GlcNAc 423 may be recovered from the environment. Nutrient scavenging via macropinocytosis is a key 424 feature of PDA (Commisso et al., 2013; Kamphorst et al., 2015). Macropinocytosis has mostly 425 been associated with scavenging of protein to recover amino acids, but lysosomal break down 426 of glycoproteins may also release sugars including GlcNAc. Additionally, ECM components, 427 including hyaluronic acid (HA), which is a polymer of GlcNAc and glucuronic acid disaccharide 428 units, may be additional sources of GlcNAc for salvage in the tumor microenvironment. Indeed, 429 in a manuscript co-submitted with this one, Kim, Halbrook, and colleagues identify HA as a 430 major source of scavenged GIcNAc (Kim et al., 2020). Our manuscript and the Kim, Halbrook et 
431 al manuscript together indicate that NAGK may take on a heightened importance in the context

432 of high GlcNAc availability and nutrient deprivation, a situation that is likely to occur within the

433 tumor microenvironment.

434 Further, the key fates of UDP-GICNAc that support tumor growth remain to be elucidated.

435 Sufficient UDP-GICNAc is required for protein glycosylation to maintain homeostasis and 436 prevent ER stress, particularly in a rapidly dividing cell. Additionally, a wide range of cancers 437 exhibit elevated O-GIcNAc, which could contribute to driving pro-tumorigenic transcriptional and 438 signaling programs. In PDA specifically, the glycan CA19-9 is currently used as a biomarker for 439 disease progression and recent studies point to a functional role for CA19-9 in tumorigenesis 440 (Engle et al., 2019). UDP-GlcNAc is also required for HA synthesis, which is present in low 441 amounts in normal pancreas but increases in PanIN lesions and PDA (Provenzano et al., 2012). 442 PDA cells are capable of producing HA in vitro (Mahlbacher et al., 1992). Depletion of 443 fibroblasts in an autochthonous PDA mouse model results in a decrease in collagen I but not $444 \mathrm{HA}$ in the tumor microenvironment, indicating that HA must be generated by another cell type, 445 possibly the tumor cells themselves (Özdemir et al., 2014). Previous studies demonstrated that 446 treatment of PDA with exogenous hyaluronidase can increase vascularization and improve drug 447 delivery to the tumor (Jacobetz et al., 2013; Provenzano et al., 2012), although a phase III 448 clinical trial reported no improvement in overall patient survival when combining pegylated 449 hyaluronidase with nab-paclitaxel plus gemcitabine (Cutsem et al., 2020). Recently, it was 450 shown that inhibiting the HBP by treatment with 6-diazo-5-oxo-I-norleucine (DON) depletes HA 451 and collagen in an orthotopic mouse model. DON treatment also increased CD8 T-cell 452 infiltration into the tumor, sensitizing the tumor to anti-PD1 therapy (Sharma et al., 2020). Thus, 453 targeting the HBP holds promise for improving the efficacy of other therapeutics. The findings of 454 the current study suggest that in addition to de novo hexosamine synthesis, targeting of This manuscript has been co-submitted with Kim et al. (2020), "Pancreatic Cancers Scavenge Hyaluronic Acid to Support Growth." 
hexosamine salvage warrants further investigation in terms of potential for therapeutic

456 intervention. Of note, an inhibitor targeting PGM3, which converts GlcNAc-6-P to GlcNAc-1-P

457 and is thus required for both de novo UDP-GIcNAc synthesis and GlcNAc recycling, showed

458 efficacy in treating gemcitabine-resistant patient-derived xenograft PDA models (Ricciardiello et

459 al., 2020), as well as in breast cancer xenografts (Ricciardiello et al., 2018).

Finally, almost nothing is currently known about the role of NAGK and GlcNAc salvage in

normal physiology. Even in non-cancerous IL-3-dependent hematopoietic cells, a substantial

462 proportion of the UDP-GlcNAc pool remains unlabeled from ${ }^{13} \mathrm{C}$-glucose (Wellen et al., 2010),

463 suggesting that salvage may contribute to UDP-GIcNAc pools in a variety of cell types.

464 However, while GFPT1 is required for embryonic development in mice, NAGK knockout mouse

465 embryos are viable (Dickinson et al., 2016). NAGK deficiency has not yet been characterized in

466 postnatal or adult mice. Perhaps GlcNAc salvage is dispensable when nutrients are available

467 and cells are not dividing, as in most healthy tissues. However, in a tumor, in which cells are

468 proliferating and nutrients are spread thin, NAGK and GIcNAc salvage may become more

469 important in feeding UDP-GIcNAc pools. Related questions include elucidating the mechanisms

470 regulating NAGK gene expression and putative post-translational modification, as well as

471 understanding the role of GALK2 in hexosamine salvage.

472 In sum, we report a key role for NAGK in feeding UDP-GIcNAc pools in PDA cells and in 473 supporting xenograft tumor growth. Further investigation will be needed to elucidate the 474 physiological functions of NAGK, as well as the mechanisms through which it supports tumor 475 growth and its potential role in modulating therapeutic responses.

476 Funding Sources: This work was supported by R01CA174761 and R01CA228339 to K.E.W.

477 This work was also funded in part under a grant with the Pennsylvania Department of Health to This manuscript has been co-submitted with Kim et al. (2020), "Pancreatic Cancers Scavenge Hyaluronic Acid to Support Growth." 
K.E.W. and I.A.B. The Department specifically disclaims responsibility for any analyses,

479 interpretations, or conclusions. I.A.B. acknowledges support of NIH Grants P30ES013508 and

480 P30CA016520. J.B. acknowledges support of NIH Grant R01CA046595. S.L.C. received 481 support from T32CA115299 and F31CA217070, as well as from a Patel Family Scholar Award.

482 H.A. was supported by post-doctoral fellowship K00CA212455. T.T. is supported by the 483 National Cancer Institute through pre-doctoral fellowship F31CA243294 and acknowledges the 484 Blavatnik Family for a predoctoral fellowship. L.I. is supported by T32 GM-07229 and T32 485 CA115299. S.T. is supported by the American Diabetes Association through post-doctoral 486 fellowship 1-18-PDF-144. Funding sources were not involved in study design, data collection 487 and interpretation, or the decision to submit the work for publication.

488 Conflict of interest: I.A.B. is a founder of Proteoform Bio and a paid consultant for Calico, 489 Chimerix, PTC Therapeutics, Takeda Pharmaceuticals, and Vivo Capital.

\section{References}

491 Akella, N.M., Ciraku, L., and Reginato, M.J. (2019). Fueling the fire: Emerging role of the 492 hexosamine biosynthetic pathway in cancer. BMC Biol. 17, 1-14.

493 Caldwell, S.A., Jackson, S.R., Shahriari, K.S., Lynch, T.P., Sethi, G., Walker, S., Vosseller, K., 494 and Reginato, M.J. (2010). Nutrient sensor O-GlcNAc transferase regulates breast cancer 495 tumorigenesis through targeting of the oncogenic transcription factor FoxM1. Oncogene 29, $496 \quad 2831-2842$.

497 Chen, R., Lai, L.A., Sullivan, Y., Wong, M., Wang, L., Riddell, J., Jung, L., Pillarisetty, V.G., 498 Brentnall, T.A., and Pan, S. (2017). Disrupting glutamine metabolic pathways to sensitize 499 gemcitabine-resistant pancreatic cancer. Sci. Rep. 7, 1-14.

This manuscript has been co-submitted with Kim et al. (2020), "Pancreatic Cancers Scavenge Hyaluronic Acid to Support Growth." 
500 Commisso, C., Davidson, S.M., Soydaner-Azeloglu, R.G., Parker, S.J., Kamphorst, J.J.,

501 Hackett, S., Grabocka, E., Nofal, M., Drebin, J.A., Thompson, C.B., et al. (2013).

502 Macropinocytosis of protein is an amino acid supply route in Ras-transformed cells. Nature 497, 503 633-637.

504 Cutsem, E. Van, Tempero, M.A., Sigal, D., Oh, D., Fazio, N., Macarulla, T., Hitre, E., Hammel, 505 P., Hendifar, A., Bates, S., et al. (2020). Randomized Phase III Trial of Pegvorhyaluronidase 506 Alfa With Nab-Paclitaxel Plus Gemcitabine for Patients With Hyaluronan-High Metastatic 507 Pancreatic Adenocarcinoma abstract. J. Clin. Oncol.

508 Denzel, M.S., and Antebi, A. (2015). Hexosamine pathway and (ER) protein quality control. 509 Curr. Opin. Cell Biol. 33, 14-18.

510 Dickinson, M.E., Flenniken, A.M., Ji, X., Teboul, L., Wong, M.D., White, J.K., Meehan, T.F., 511 Weninger, W.J., Westerberg, H., Adissu, H., et al. (2016). High-throughput discovery of novel 512 developmental phenotypes. Nature 537, 508-514.

513 Doench, J.G., Fusi, N., Sullender, M., Hegde, M., Vaimberg, E.W., Donovan, K.F., Smith, I., 514 Tothova, Z., Wilen, C., Orchard, R., et al. (2016). Optimized sgRNA design to maximize activity 515 and minimize off-target effects of CRISPR-Cas9. Nat. Biotechnol. 34, 184-191.

516 Edgar, R., Domrachev, M., and Lash, A.E. (2002). Gene Expression Omnibus: NCBI gene 517 expression and hybridization array data repository. Nucleic Acids Res. 30, 207-210.

518 Engle, D.D., Tiriac, H., Rivera, K.D., Pommier, A., Oni, T.E., Alagesan, B., Lee, E.J., Yao, M.A., 519 Lucito, M.S., Spielman, B., et al. (2019). The Glycan CA19-9 Promotes Pancreatitis and 520 Pancreatic Cancer in Mice. 364, 1156-1162.

This manuscript has been co-submitted with Kim et al. (2020), "Pancreatic Cancers Scavenge Hyaluronic Acid to Support Growth." 
521 Ferrer, C.M., Lu, T.Y., Bacigalupa, Z.A., Katsetos, C.D., Sinclair, D.A., and Reginato, M.J.

522 (2017). O-GlcNAcylation regulates breast cancer metastasis via SIRT1 modulation of FOXM1

523 pathway. Oncogene 36, 559-569.

524 Granovsky, M., Fata, J., Pawling, J., Muller, W.J., Khokha, R., and Dennis, J.W. (2000).

525 Suppression of tumor growth and metastasis in Mgat5-deficient mice. Nat. Med. 6, 306-312.

526 Gu, Y., Mi, W., Ge, Y., Liu, H., Fan, Q., Han, C., Yang, J., Han, F., Lu, X., and Yu, W. (2010).

527 GlcNAcylation plays an essential role in breast cancer metastasis. Cancer Res. 70, 6344-6351.

528 Guillaumond, F., Leca, J., Olivares, O., Lavaut, M.-N.N., Vidal, N., Berthezène, P., Dusetti, N.J.,

529 Loncle, C., Calvo, E., Turrini, O., et al. (2013). Strengthened glycolysis under hypoxia supports

530 tumor symbiosis and hexosamine biosynthesis in pancreatic adenocarcinoma. Proc. Natl. Acad.

531 Sci. U. S. A. 110, 3919-3924.

532 Guo, H., Zhang, B., Nairn, A. V., Nagy, T., Moremen, K.W., Buckhaults, P., and Pierce, M.

533 (2017). O-Linked N-Acetylglucosamine (O-GlcNAc) Expression Levels Epigenetically Regulate 534 Colon Cancer Tumorigenesis by Affecting the Cancer Stem Cell Compartment via Modulating

535 Expression of Transcriptional Factor MYBL1. J. Biol. Chem. 292, 4123-4137.

536 Guo, J.Y., Chen, H.Y., Mathew, R., Fan, J., Strohecker, A.M., Karsli-Uzunbas, G., Kamphorst, 537 J.J., Chen, G., Lemons, J.M.S., Karantza, V., et al. (2011). Activated Ras requires autophagy to 538 maintain oxidative metabolism and tumorigenesis. Genes Dev. 25, 460-470.

539 Guo, L., Worth, A.J., Mesaros, C., Snyder, N.W., Jerry, D., and Blair, I.A. (2016).

540 Diisopropylethylamine/hexafluoroisopropanol-mediated ion- pairing UHPLC-MS for phosphate

541 and carboxylate metabolite analysis: utility for studying cellular metabolism. Rapid Commun

542 Mass Spectrom. 30, 1835-1845.

This manuscript has been co-submitted with Kim et al. (2020), "Pancreatic Cancers Scavenge Hyaluronic Acid to Support Growth." 
543 Halbrook, C.J., and Lyssiotis, C.A. (2017). Employing Metabolism to Improve the Diagnosis and

544 Treatment of Pancreatic Cancer. Cancer Cell 31, 5-19.

545 Housley, M.P., Rodgers, J.T., Udeshi, N.D., Kelly, T.J., Shabanowitz, J., Hunt, D.F., Puigserver, 546 P., and Hart, G.W. (2008). O-GlcNAc regulates FoxO activation in response to glucose. J. Biol.

547 Chem. 283, 16283-16292.

548 Jacobetz, M.A., Chan, D.S., Neesse, A., Bapiro, T.E., Cook, N., Frese, K.K., Feig, C.,

549 Nakagawa, T., Caldwell, M.E., Zecchini, H.I., et al. (2013). Hyaluronan impairs vascular function 550 and drug delivery in a mouse model of pancreatic cancer. Gut $62,112-120$.

551 Kamphorst, J.J., Nofal, M., Commisso, C., Hackett, S.R., Lu, W., Grabocka, E., Vander Heiden, 552 M.G., Miller, G., Drebin, J.A., Bar-Sagi, D., et al. (2015). Human Pancreatic Cancer Tumors Are 553 Nutrient Poor and Tumor Cells Actively Scavenge Extracellular Protein. Cancer Res. 75, 544554553.

555 Kim, P.K., Halbrook, C.J., Kerk, S.A., Wisner, S., Kremer, D., Sajjakulnukit, P., Hou, S.W., 556 Thurston, G., Anand, A., Yan, L., et al. (2020). Hyaluronic Acid Fuels Pancreatic Cancer 557 Growth. BioRxiv.

558 Lau, K.S., Partridge, E.A., Grigorian, A., Silvescu, C.I., Reinhold, V.N., Demetriou, M., and 559 Dennis, J.W. (2007). Complex N-Glycan Number and Degree of Branching Cooperate to 560 Regulate Cell Proliferation and Differentiation. Cell 129, 123-134.

561 Li, D., Li, Y., Wu, X., Li, Q., Yu, J., Gen, J., and Zhang, X.-L. (2008). Knockdown of Mgat5

562 Inhibits Breast Cancer Cell Growth with Activation of CD4 + T Cells and Macrophages . J.

563 Immunol. 180, 3158-3165.

This manuscript has been co-submitted with Kim et al. (2020), "Pancreatic Cancers Scavenge Hyaluronic Acid to Support Growth." 
564 Lynch, T.P., Ferrer, C.M., Jackson, S.R.E., Shahriari, K.S., Vosseller, K., and Reginato, M.J.

565 (2012). Critical role of O-linked $\beta-\mathrm{N}$-acetylglucosamine transferase in prostate cancer invasion, 566 angiogenesis, and metastasis. J. Biol. Chem. 287, 11070-11081.

567 Lyssiotis, C.A., and Kimmelman, A.C. (2017). Metabolic Interactions in the Tumor

568 Microenvironment. Trends Cell Biol. 27, 863-875.

569 Mahlbacher, V., Sewing, A., Elsässer, H.P., and Kern, H.F. (1992). Hyaluronan is a secretory

570 product of human pancreatic adenocarcinoma cells. Eur. J. Cell Biol. 58, 28-34.

571 Mereiter, S., Balmaña, M., Campos, D., Gomes, J., and Reis, C.A. (2019). Glycosylation in the 572 Era of Cancer-Targeted Therapy: Where Are We Heading? Cancer Cell 36, 6-16.

573 Moloughney, J.G.G., Kim, P.K.K., Vega-cotto, N.M.M., Wu, C.-C., Zhang, S., Adlam, M., Lynch, 574 T., Chou, P.-C., Rabinowitz, J.D.D., Werlen, G., et al. (2016). mTORC2 Responds to Glutamine 575 Catabolite Levels to Modulate the Hexosamine Biosynthesis Enzyme GFAT1. Mol. Cell 63, $576 \quad 811-826$.

577 Moseley, H.N.B., Lane, A.N., Belshoff, A.C., Higashi, R.M., and Fan, T.W.M. (2011). A novel 578 deconvolution method for modeling UDP-N-acetyl-D-glucosamine biosynthetic pathways based 579 on $13 \mathrm{C}$ mass isotopologue profiles under non-steady-state conditions. BMC Biol. 9.

580 Munkley, J. (2019). The glycosylation landscape of pancreatic cancer (Review). Oncol. Lett. 17, $581 \quad 2569-2575$.

582 Özdemir, B.C., Pentcheva-Hoang, T., Carstens, J.L., Zheng, X., Wu, C.C., Simpson, T.R., 583 Laklai, H., Sugimoto, H., Kahlert, C., Novitskiy, S. V., et al. (2014). Depletion of carcinoma584 associated fibroblasts and fibrosis induces immunosuppression and accelerates pancreas

This manuscript has been co-submitted with Kim et al. (2020), "Pancreatic Cancers Scavenge Hyaluronic Acid to Support Growth." 
cancer with reduced survival. Cancer Cell 25, 719-734.

586

587

588

Park, S.Y., Kim, H.S., Kim, N.H., Ji, S., Cha, S.Y., Kang, J.G., Ota, I., Shimada, K., Konishi, N., Nam, H.W., et al. (2010). Snail1 is stabilized by O-GIcNAc modification in hyperglycaemic condition. EMBO J. 29, 3787-3796.

Pei, H., Li, L., Fridley, B.L., Jenkins, G.D., Kalari, K.R., Lingle, W., Petersen, G., Lou, Z., and Wang, L. (2009). FKBP51 Affects Cancer Cell Response to Chemotherapy by Negatively Regulating Akt. Cancer Cell 16, 259-266.

Provenzano, P.P., Cuevas, C., Chang, A.E., Goel, V.K., Von Hoff, D.D., and Hingorani, S.R. (2012). Enzymatic Targeting of the Stroma Ablates Physical Barriers to Treatment of Pancreatic Ductal Adenocarcinoma. Cancer Cell 21, 418-429.

Rahib, L., Smith, B.D., Aizenberg, R., Rosenzweig, A.B., Fleshman, J.M., and Matrisian, L.M. (2014). Projecting cancer incidence and deaths to 2030: The unexpected burden of thyroid, liver, and pancreas cancers in the united states. Cancer Res. 74, 2913-2921.

Ricciardiello, F., Votta, G., Palorini, R., Raccagni, I., Brunelli, L., Paiotta, A., Tinelli, F., D’Orazio, G., Valtorta, S., De Gioia, L., et al. (2018). Inhibition of the Hexosamine Biosynthetic Pathway by targeting PGM3 causes breast cancer growth arrest and apoptosis. Cell Death Dis. 9.

Ricciardiello, F., Gang, Y., Palorini, R., Li, Q., Giampà, M., Zhao, F., You, L., La Ferla, B., De Vitto, H., Guan, W., et al. (2020). Hexosamine pathway inhibition overcomes pancreatic cancer resistance to gemcitabine through unfolded protein response and EGFR-Akt pathway modulation. Oncogene 4103-4117.

Ryczko, M.C., Pawling, J., Chen, R., Abdel Rahman, A.M., Yau, K., Copeland, J.K., Zhang, C.,

This manuscript has been co-submitted with Kim et al. (2020), "Pancreatic Cancers Scavenge Hyaluronic Acid to Support Growth." 
Surendra, A., Guttman, D.S., Figeys, D., et al. (2016). Metabolic Reprogramming by Hexosamine Biosynthetic and Golgi N-Glycan Branching Pathways. Sci. Rep. 6, 23043.

Sanjana, N.E., Shalem, O., and Zhang, F. (2014). Sanjana, Shalem et Zhang. Nat. Med. 11, 783-784.

Schneider, C.A., Rasband, W.S., and Eliceiri, K.W. (2012). NIH Image to ImageJ: 25 years of image analysis. Nat. Methods 9, 671-675.

Sharma, N.S., Saluja, A., Banerjee, S., Sharma, N.S., Gupta, V.K., Garrido, V.T., Hadad, R., Durden, B.C., Kesh, K., Giri, B., et al. (2020). Targeting tumor-intrinsic hexosamine biosynthesis sensitizes pancreatic cancer to anti-PD1 therapy Graphical abstract Find the latest version : Targeting tumor-intrinsic hexosamine biosynthesis sensitizes pancreatic cancer to anti-PD1 therapy. 130, 451-465.

Steenackers, A., Olivier-Van Stichelen, S., Baldini, S.F., Dehennaut, V., Toillon, R.A., Le Bourhis, X., El Yazidi-Belkoura, I., and Lefebvre, T. (2016). Silencing the nucleocytoplasmic OGIcNAc transferase reduces proliferation, adhesion, and migration of cancer and fetal human colon cell lines. Front. Endocrinol. (Lausanne). 7, 1-11.

Swamy, M., Pathak, S., Grzes, K.M., Damerow, S., Sinclair, L. V, van Aalten, D.M.F., and Cantrell, D.A. (2016). Glucose and glutamine fuel protein O-GIcNAcylation to control T cell selfrenewal and malignancy. Nat. Immunol. 17, 1-11.

Tang, Z., Kang, B., Li, C., Chen, T., and Zhang, Z. (2019). GEPIA2: an enhanced web server for large-scale expression profiling and interactive analysis. Nucleic Acids Res. 47, W556-W560.

Taylor, R.P., Parker, G.J., Hazel, M.W., Soesanto, Y., Fuller, W., Yazzie, M.J., and McClain, This manuscript has been co-submitted with Kim et al. (2020), "Pancreatic Cancers Scavenge Hyaluronic Acid to Support Growth." 
D.A. (2008). Glucose deprivation stimulates O-GlcNAc modification of proteins through up-

628 regulation of O-linked N-acetylglucosaminyltransferase. J. Biol. Chem. 283, 6050-6057.

631 Wellen, K.E., Lu, C., Mancuso, A., Lemons, J.M.S.S., Ryczko, M., Dennis, J.W., Rabinowitz,

632 J.D., Coller, H.A., and Thompson, C.B. (2010). The hexosamine biosynthetic pathway couples growth factor-induced glutamine uptake to glucose metabolism. Genes Dev. 24, 2784-2799.

634 Wyant, G.A., Abu-Remaileh, M., Frenkel, E.M., Laqtom, N.N., Dharamdasani, V., Lewis, C.A., 635 Chan, S.H., Heinze, I., Ori, A., and Sabatini, D.M. (2018). NUFIP1 is a ribosome receptor for 636 starvation-induced ribophagy. Science (80-. ). 360, 751-758.

637 Ying, H., Kimmelman, A.C., Lyssiotis, C.A., Hua, S., Chu, G.C., Fletcher-Sananikone, E., 638 Locasale, J.W., Son, J., Zhang, H., Coloff, J.L., et al. (2012). Oncogenic kras maintains 639 pancreatic tumors through regulation of anabolic glucose metabolism. Cell 149, 656-670.

640 Zhou, X., Chen, H., Wang, Q., Zhang, L., and Zhao, J. (2011). Knockdown of Mgat5 inhibits 641 CD133+ human pulmonary adenocarcinoma cell growth in vitro and in vivo. Clin. Invest. Med. 64234, E155-62. 
bioRxiv preprint doi: https://doi.org/10.1101/2020.09.13.294116; this version posted June 21, 2021. The copyright holder for this preprint (which was not certified by peer review) is the author/funder. All rights reserved. No reuse allowed without permission.

A

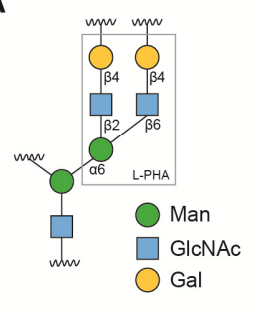

B

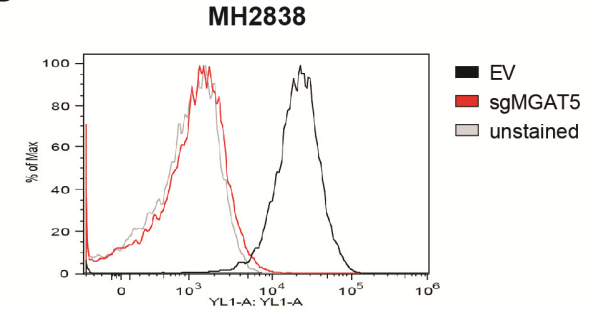

LPHA binding

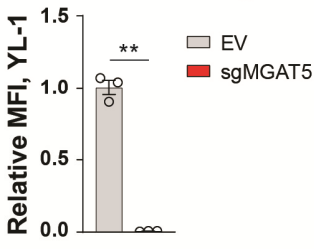

C

PANC-1, glucose

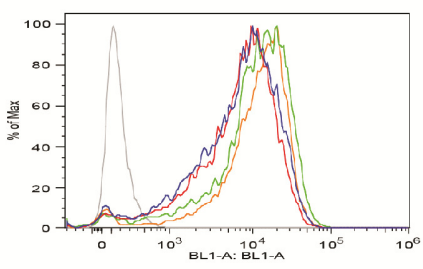

D

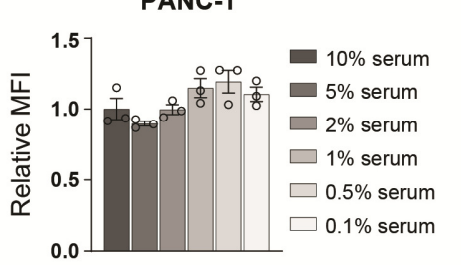

PANC-1, glutamine

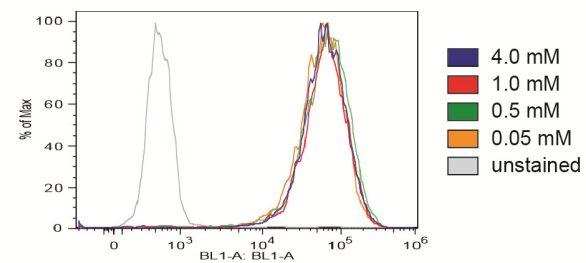

LPHA binding

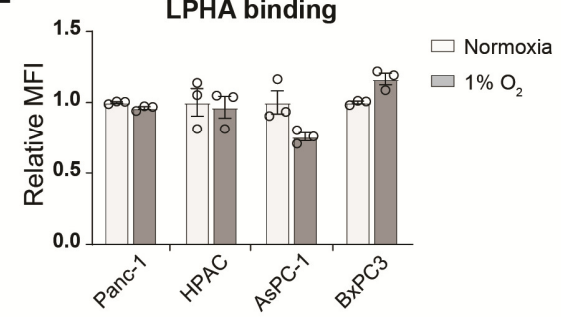

$\mathbf{F}$

MIA PaCa-2

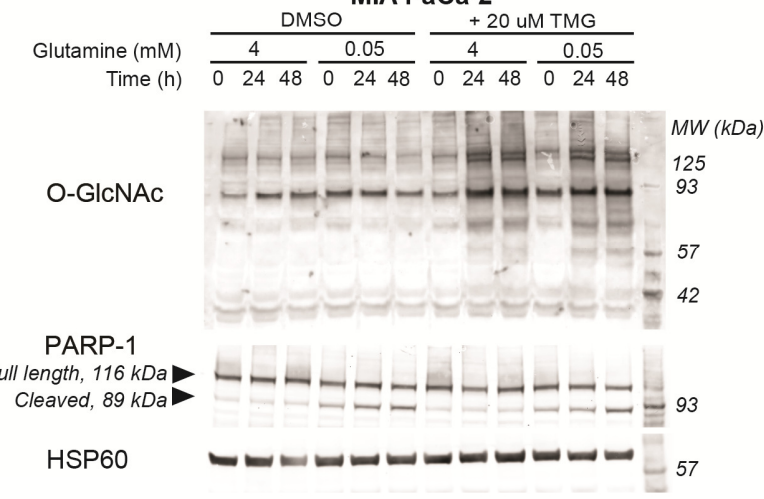

Supplemental Figure 1: LPHA binding detects MGAT5-dependent glycans.

A) Diagram of LPHA binding. LPHA recognizes specifically the $\beta 1-6$ linkage established by MGAT5. B) LPHA binding on MGAT5 knockout cells isolated from a KPCY tumor (Li, Byrne et al., 2018), representative flow plot and quantification. Graph shows MFI relative to control cells. Statistical significance was calculated by unpaired t-test. C) Representative flow plots for LPHA binding graphed in Fig. 1D, E on PANC-1 cells in low glucose and low glutamine. D-E) LPHA binding in PDA cells in low nutrients. Cells were incubated in the indicated concentrations of serum (D) or oxygen (E) for 48 hours and then analyzed by flow cytometry. Graph shows MFI relative to control condition. F) Western blot for O-GIcNAc and PARP in MIA PaCa-2 cells cultured in the indicated concentrations of glutamine with or without TMG for the indicated time. Statistical significance was calculated by one-way ANOVA (D) and unpaired t-test (E). Panels B) - E) are representative of at least two independent experimental replicates. ${ }^{*}, p \leq 0.05 ;{ }^{* *}, p \leq 0.01 ;{ }^{* *}, p \leq 0.001$. 
bioRxiv preprint doi: https://doi.org/10.1101/2020.09.13.294116; this version posted June 21, 2021. The copyright holder for this preprint (which was not certified by peer review) is the author/funder. All rights reserved. No reuse allowed without permission.

A

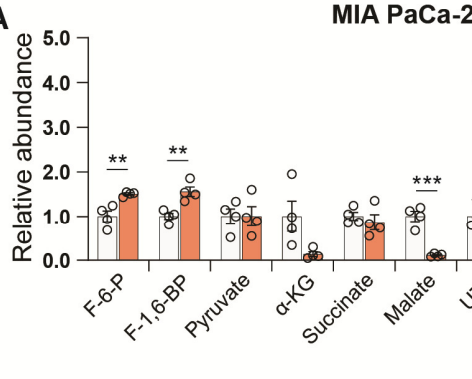

Ca-2

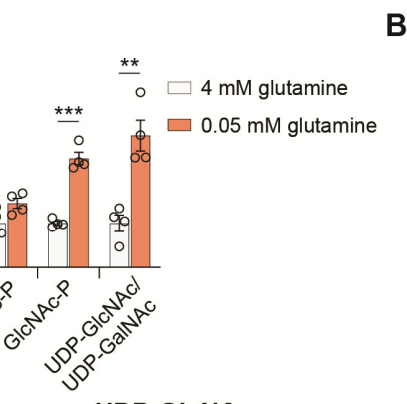

B

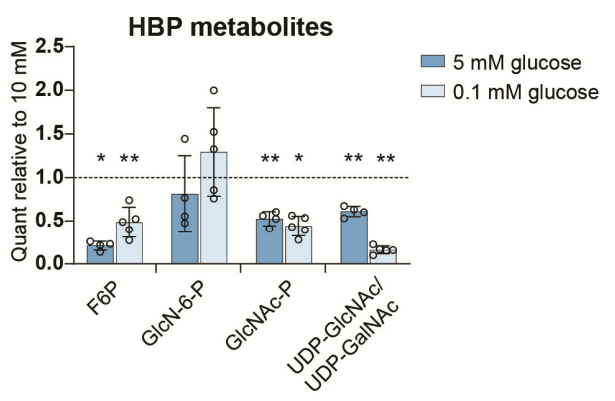

C
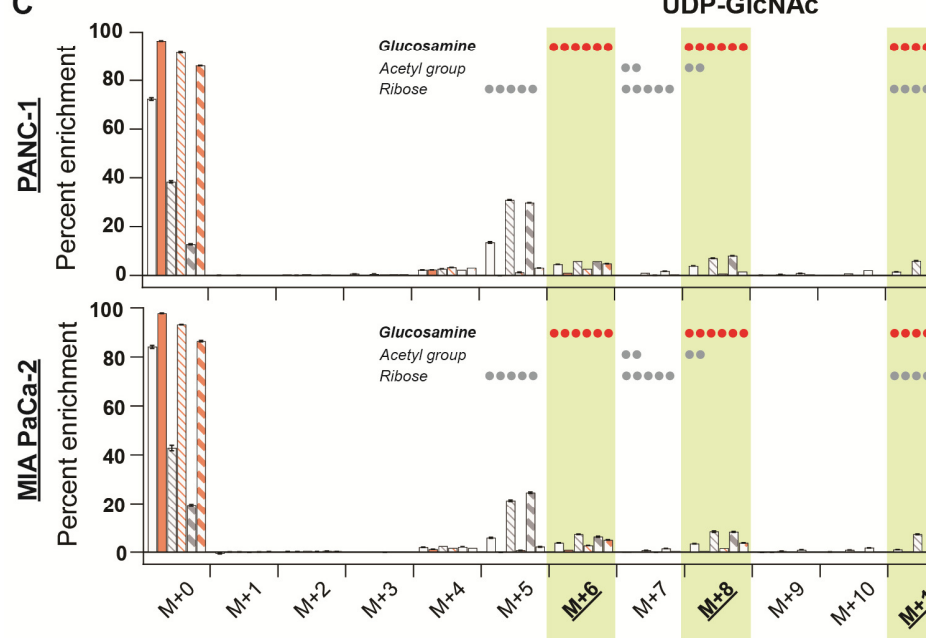

D
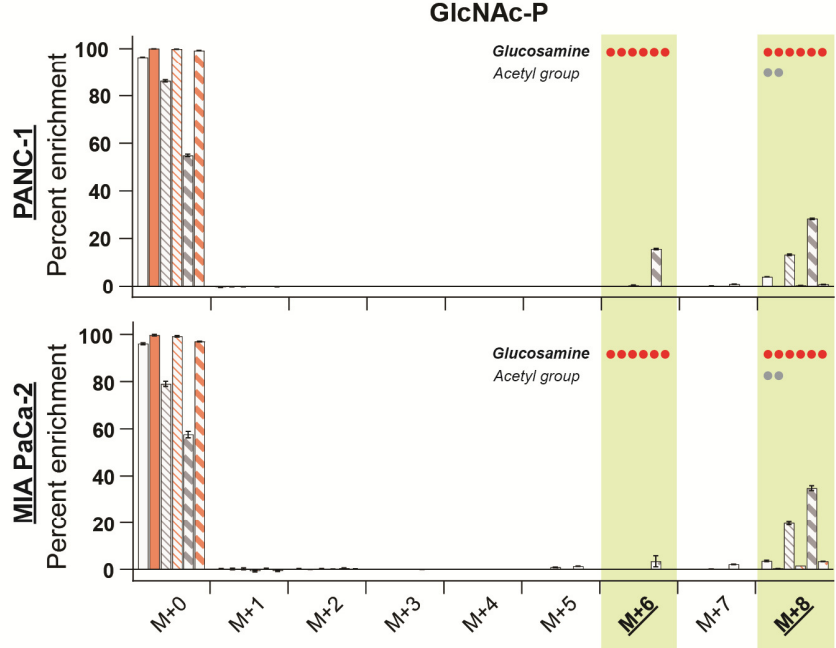

$\mathrm{E}$

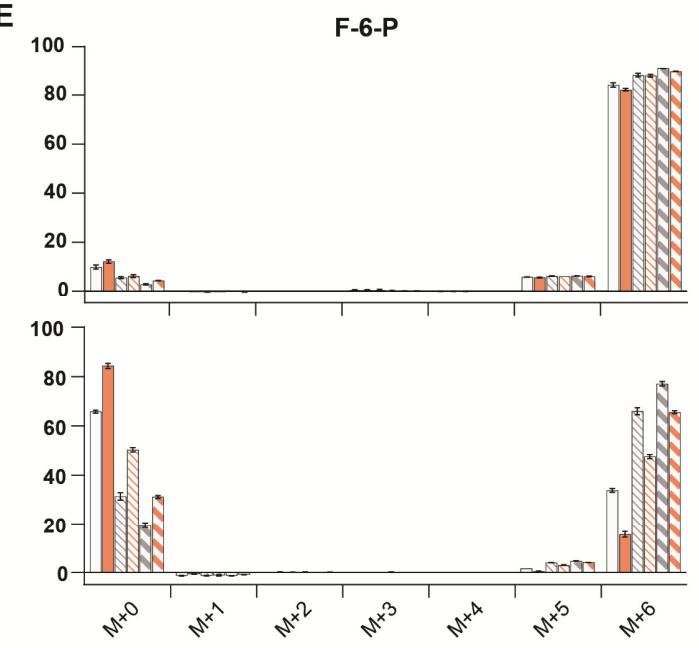

Supplemental Figure S2.1: De novo hexosamine synthesis is suppressed in low glutamine conditions.

A) Metabolite measurements in MIA PaCa-2 cells after culture for 48 hours in $0.05 \mathrm{mM}$ glutamine. Quantification is normalized to 4 mM glutamine condition. Statistical significance was calculated by unpaired t-test. Mean +/- SEM of four biological replicates is represented. B) Measurement of HBP metabolites in PANC-1 cells after culture for 48 hours in $5 \mathrm{mM}$ or $0.1 \mathrm{mM}$ glucose. Mean +/- SEM of four (5 mM) or five (0.1 mM) biological replicates is represented. Statistical significance was calculated by unpaired t-test comparing each low glucose condition to the $10 \mathrm{mM}$ glucose control in each experiment. C) Measurement of $13 \mathrm{C}$ glucose incorporation into UDP-GIcNAc in high and low glutamine. Mean $+/-$ SEM of three biological replicates is represented. D) Measurement of $13 \mathrm{C}$ glucose incorporation into GIcNAc-P in high and low glutamine. Mean $+/-$ SEM of three biological replicates is represented. For (C-D), components of molecule labeled in each isotopologue are indicated, with dots representing the number of carbons; highlighted panels identify glucosamine ring labeling. E) Measurement of $13 \mathrm{C}$ glucose into fructose-6-phosphate in high and low glutamine. Mean $+/-$ SEM of three biological replicates is represented. *, $p \leq 0.05 ;{ }^{* *}, p \leq 0.01 ;{ }^{* *}, p \leq 0.001$.

This manuscript has been co-submitted with Kim et al. (2020), "Pancreatic Cancers Scavenge Hyaluronic Acid to Support Growth." 
bioRxiv preprint doi: https://doi.org/10.1101/2020.09.13.294116; this version posted June 21, 2021. The copyright holder for this preprint (which was not certified by peer review) is the author/funder. All rights reserved. No reuse allowed without permission.

A

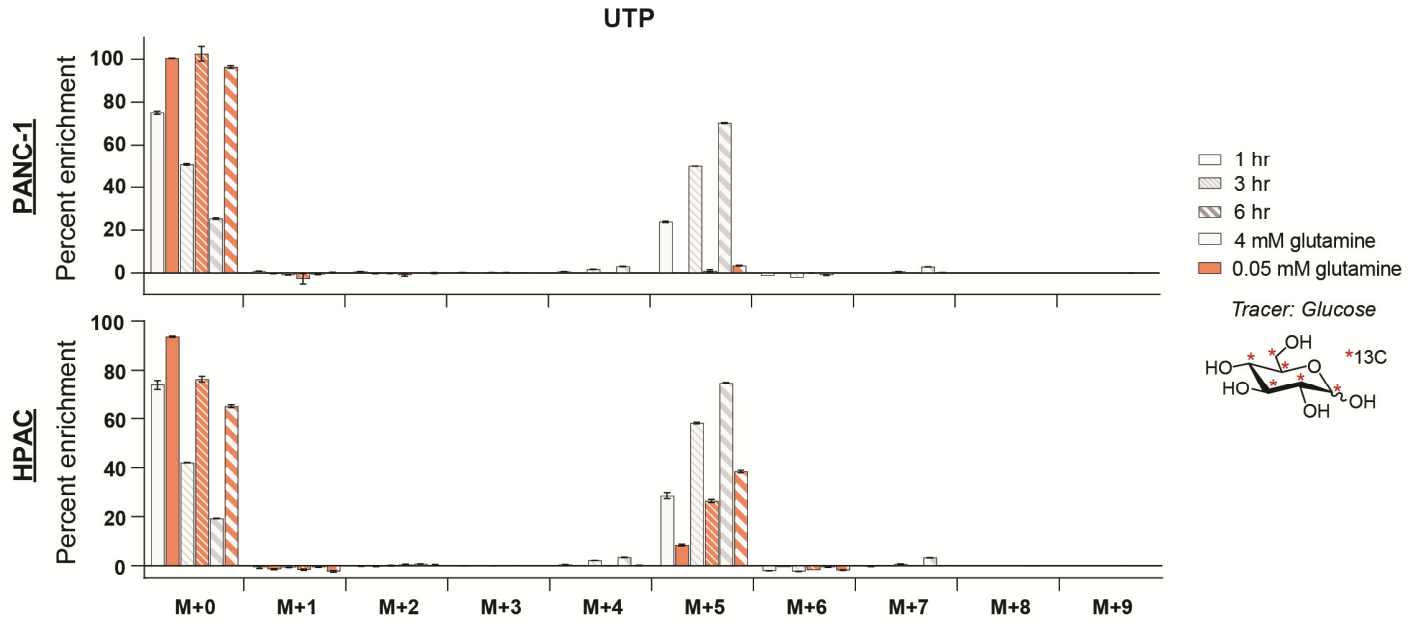

B

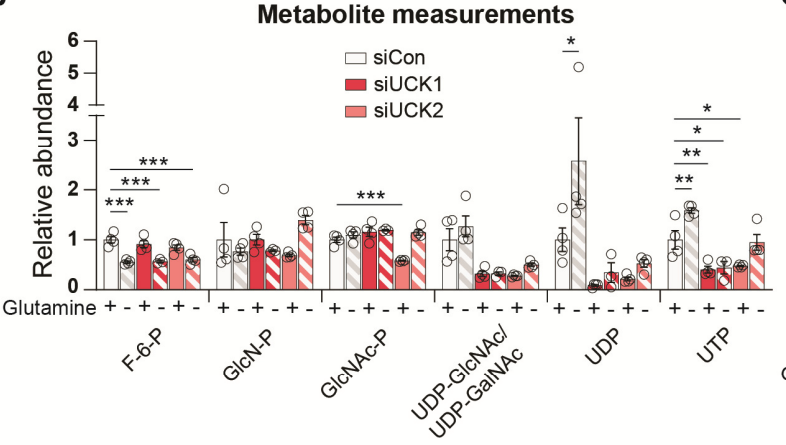

C

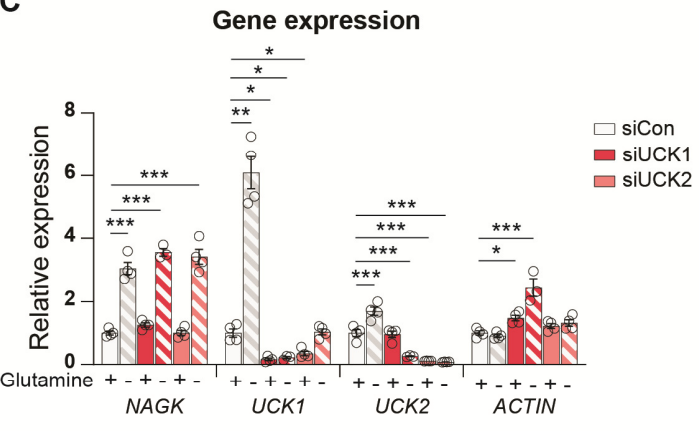

\section{D}

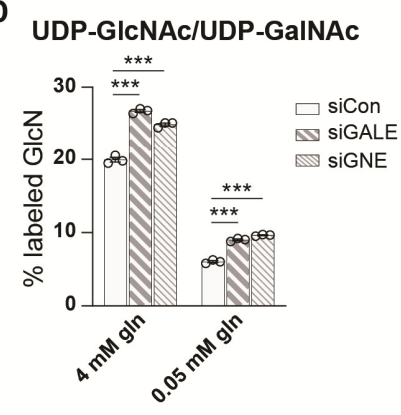

E

Gene Expression

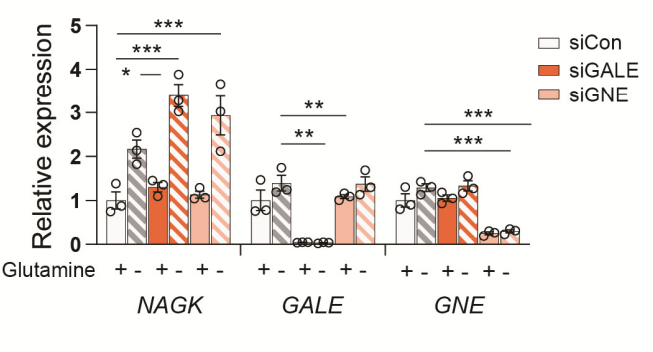

Supplemental Figure S2.2: Uridine is salvaged in glutamine restricted conditions.

A) Measurement of incorporation of $13 \mathrm{C}$ glucose into uridine triphosphate (UTP) in high and low glutamine. Mean $+/$ - SEM of three biological replicates is represented. B) Measurement of metabolites in PANC-1 cells after transfection with the indicated siRNAs and incubation in $4 \mathrm{mM}(+)$ or $0.05 \mathrm{mM}(-)$ glutamine for 48 hours. Mean +/- SEM of four biological replicates is represented. C) Gene expression of the indicated genes in PANC-1 cells after transfection with the indicated siRNAs and incubation in $4 \mathrm{mM} \mathrm{(+)}$ or $0.05 \mathrm{mM}(-)$ glutamine for 48 hours. Mean +/- SEM of four biological replicates is represented. D) Measurement of incorporation of $13 \mathrm{C}$ glucose into UDP-GIcNAC in PANC-1 cells transfected with the indicated siRNAs and incubated in $4 \mathrm{mM}$ or $0.05 \mathrm{mM}$ glutamine for 48 hours. Mean +/- SEM of three biological replicates is represented. E) Gene expression of the indicated genes in PANC-1 cells after transfection with the indicated siRNAs and incubation in $4 \mathrm{mM}(+)$ or $0.05(-) \mathrm{mM}$ glutamine for 48 hours. Mean $+/$ - SEM of three biological replicates is represented. *, $p \leq 0.05 ;{ }^{* *}, p \leq 0.01 ;{ }^{* * *}, p \leq 0.001$. 
bioRxiv preprint doi: https://doi.org/10.1101/2020.09.13.294116; this version posted June 21, 2021. The copyright holder for this preprint (which was not certified by peer review) is the author/funder. All rights reserved. No reuse allowed without permission.

A

PANC-1

MIA PaCa-2
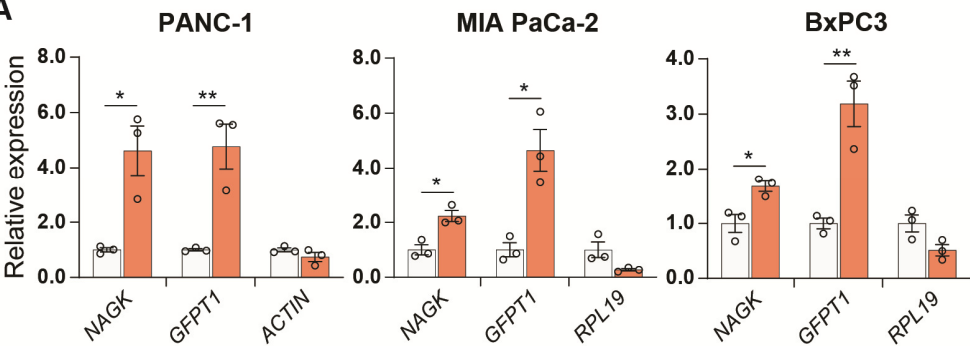

$\square 4 \mathrm{mM}$ glutamine

$0.05 \mathrm{mM}$ glutamine

B

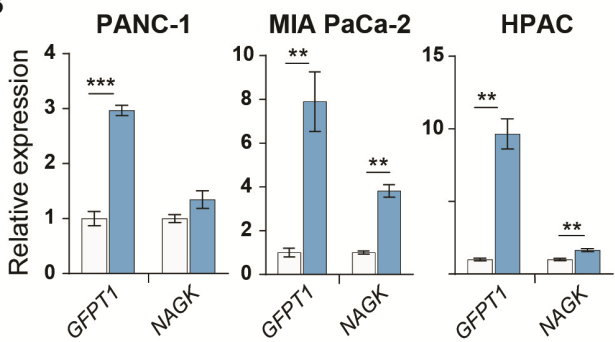

$\square 10 \mathrm{mM}$ glucose
$\square 0.1 \mathrm{mM}$ glucose

C

Glucose (mM)

Glutamine (mM)

$M W(k D a) \quad 31$
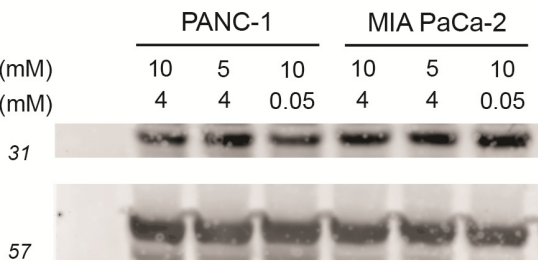

D

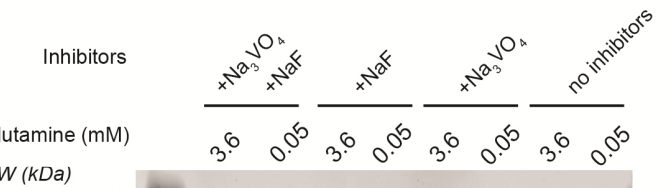

MW (kDa)

NAGK

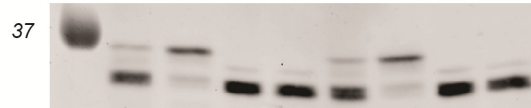

NAGK

low exposure

37

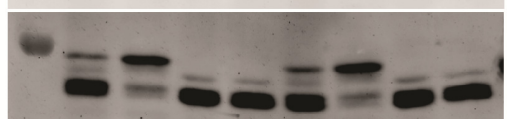

NAGK

high exposure

50

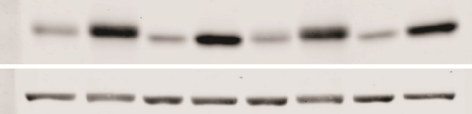

pAKT (S473)

viniculin

100

Supplemental Figure S2.3: NAGK protein expression does not increase in low glutamine despite increase in NAGK gene expression. A) Gene expression of the indicated genes in PDA cell lines after incubation in $4 \mathrm{mM}$ or $0.05 \mathrm{mM}$ glutamine for 48 hours. Mean +/- SEM of three biological replicates is represented. Statistical significance was determined by unpaired t-test. B) Gene expression of the indicated genes in PDA cell lines after incubation in $10 \mathrm{mM}$ or $0.1 \mathrm{mM}$ glucose for 48 hours. Mean +/- SEM of three biological replicates is represented. Statistical significance was determined by unpaired t-test. C) Western blot for NAGK in low nutrient conditions. PANC-1 and MIA PaCa-2 cells were cultured in the indicated concentrations of glucose and glutamine for 48 hours. D) Western blot for NAGK in low nutrient conditions. PANC-1 cells were cultured in the indicated glutamine concentrations and lysates were prepared with or without phosphatase inhibitors. Aband shift is observed for $\mathrm{NAGK}$ in lysates with $\mathrm{Na}_{3} \mathrm{VO}_{4}$. ${ }^{*}, \mathrm{p} \leq 0.05 ;{ }^{* *}, \mathrm{p} \leq 0.01 ;{ }^{* *}, \mathrm{p} \leq 0.001$. 
bioRxiv preprint doi: https://doi.org/10.1101/2020.09.13.294116; this version posted June 21, 2021. The copyright holder for this preprint (which was not certified by peer review) is the author/funder. All rights reserved. No reuse allowed without permission.

A

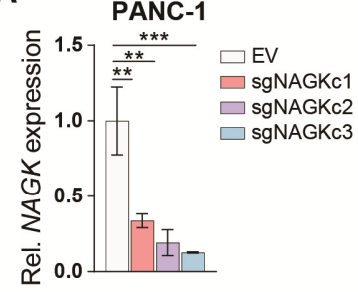

C

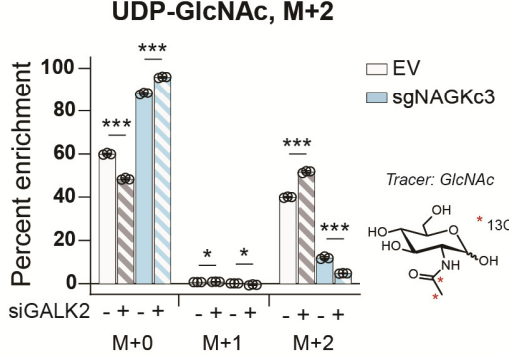

E

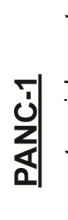

B

PANC-1

$M W(k D a)$

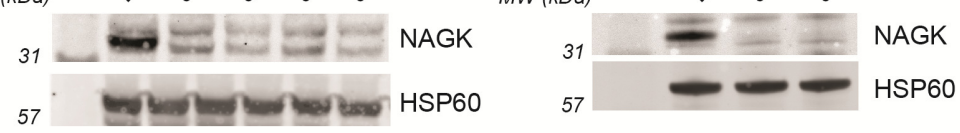

MIA PaCa-2
D

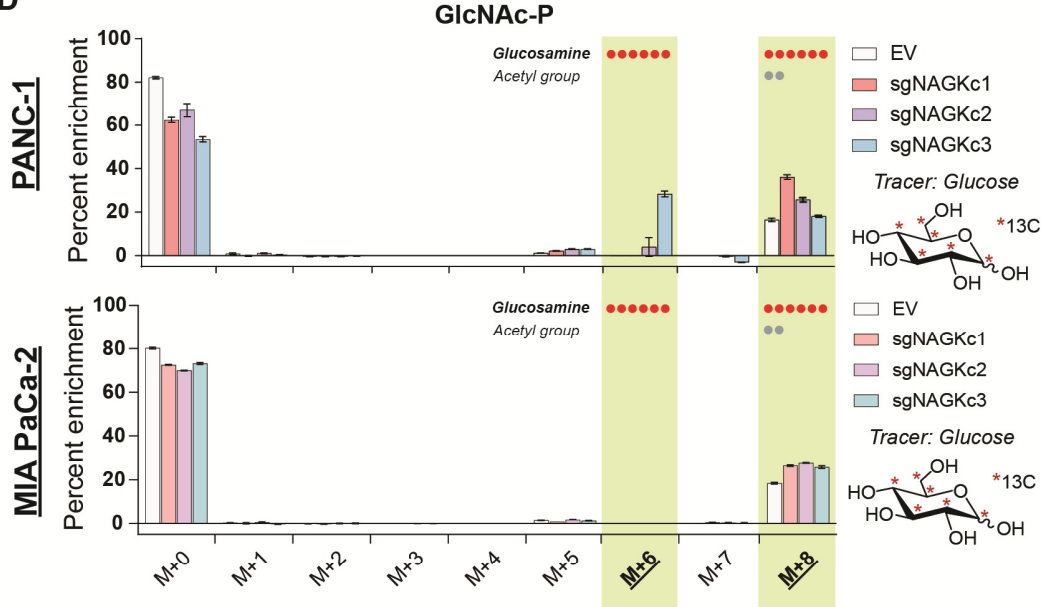

UDP-GIcNAc/UDP-GaINAC
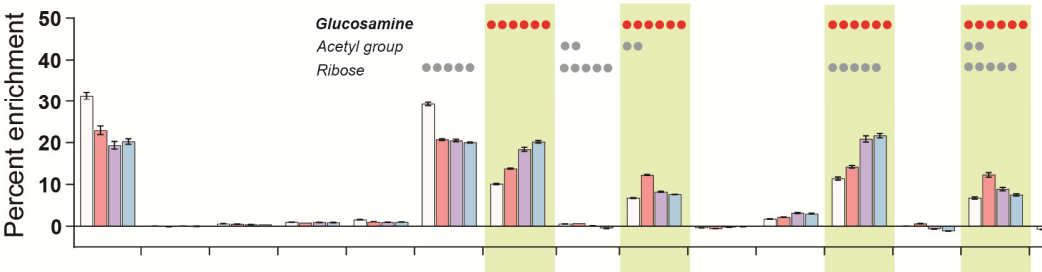

$\square \mathrm{EV}$

$\square$ sgNAGK $\mathrm{C1}$

$\square$ sgNAGK c2

$\square$ sgNAGK c3

Tracer: Glucose

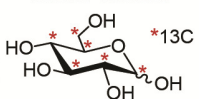

ปั

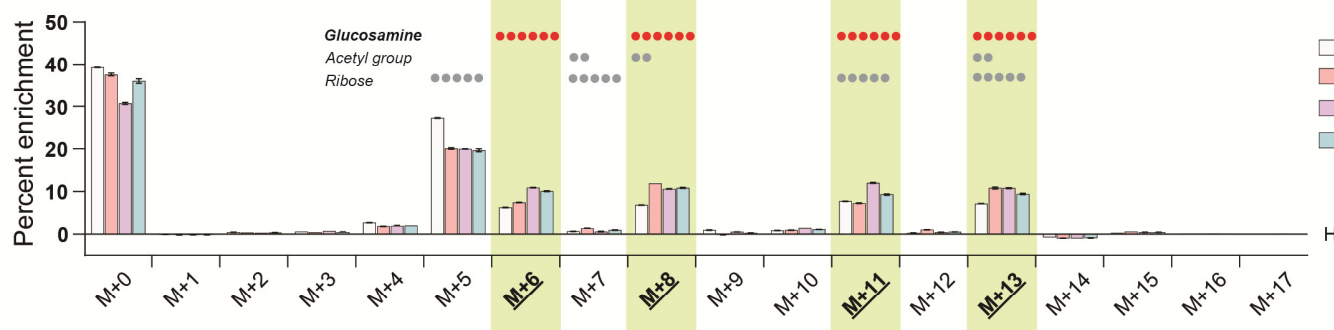

EV

sgNAGK c1

sgNAGK C2

sgNAGK C3

Tracer: Glucose 管

Supplemental Figure S3.1: NAGK knockout cells show increased enrichment of $13 \mathrm{C}$ glucose into hexosamine intermediates.

A) Gene expression of NAGK in PANC-1 NAGK CRISPR cells. Mean +/- SEM of three biological replicates is represented. Statistical significance was determined by one-way ANOVA. B) Western blot for NAGK and HSP60 in PANC-1 (left) and MIA PaCa-2 (right) NAGK CRISPR knockout cells. C) Measurement of incorporation of $13 \mathrm{C}$ GlcNAc labeled on the acetyl group into UDP-GIcNAc in PANC-1 NAGK knockout cells. Cells were incubated with $10 \mathrm{mM} 13 \mathrm{C}$ GICNAc for 3 hours. Mean +/- SEM of three biological replicates is represented. Statistical significance was determined by unpaired t-test comparing siCon and siGALK2 for each clone. D) Measurement of incorporation of $13 \mathrm{C}$ glucose into GIcNAc-P in NAGK knockout cells. Mean $+/$ - SEM of three biological replicates is represented. E) Measurement of incorporation of $13 \mathrm{C}$ glucose into UDP-GIcNAc in NAGK knockout cells. Mean +/- SEM of three biological replicates is represented. For (D-E), components of molecule labeled in each isotopologue are indicated, with dots representing the number of carbons; highlighted panels identify glucosamine ring labeling. ${ }^{*}, p \leq 0.05 ;{ }^{* *}, p \leq 0.01 ;{ }^{* * *}, p \leq 0.01$.

654 This manuscript has been co-submitted with Kim et al. (2020), "Pancreatic Cancers Scavenge Hyaluronic Acid to Support Growth." 
bioRxiv preprint doi: https://doi.org/10.1101/2020.09.13.294116; this version posted June 21, 2021. The copyright holder for this preprint (which was not certified by peer review) is the author/funder. All rights reserved. No reuse allowed without permission.

A

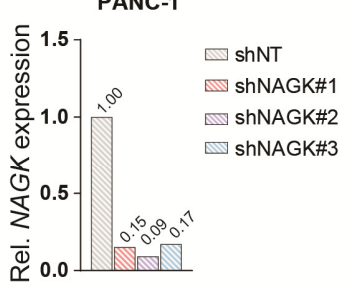

B

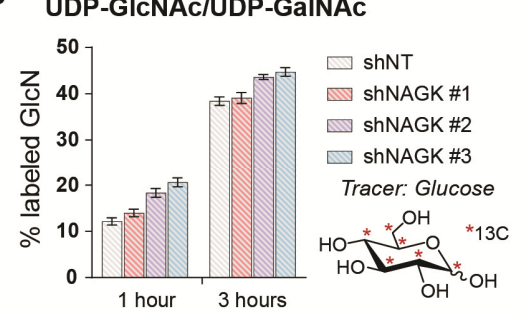

C

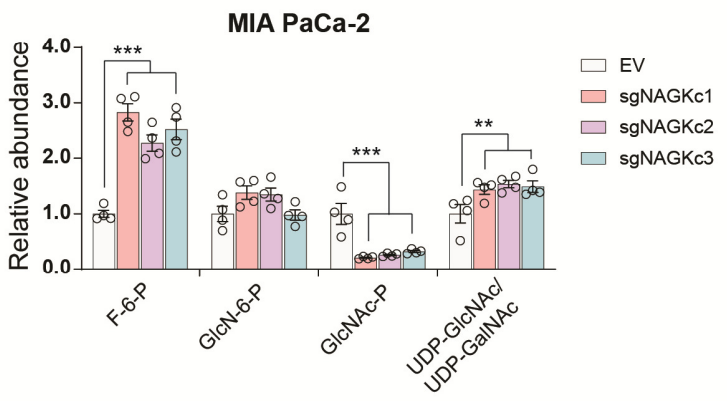

D

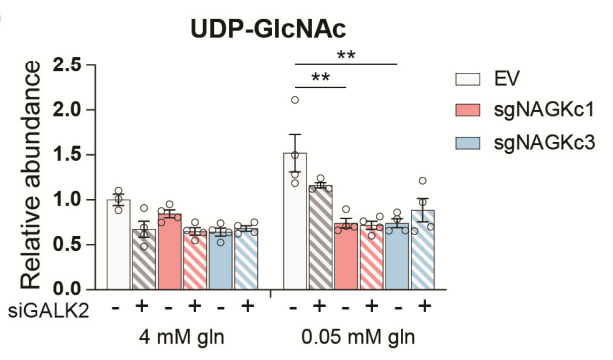

Supplementary Figure S3.2: HBP metabolites in NAGK KO cells.

A) Gene expression of NAGK in PANC-1 cells transfected with shRNA against NAGK. One biological sample is represented. B) Incorporation of 13C glucose into the glucosamine ring of IJDP-GIcNAc in PANC-1 cells transfected with the indicated shRNAs targeting NAGK Mean +l- SFM of three biological replicates is represented.C) Measurement of HBP metabolites in MIA PaCa-2 NAGK knockout cells cultured in 4 mM glutamine. Mean +/SEM of four biological replicates is represented. Statistical significance was calculated by unpaired t-test comparing the mean of the three CRISPR clones and the empty vector control. D) Measurement of UDP-GlcNAc in PANC-1 NAGK knockout cells. Mean +/- SEM of four biological replicates is represented. Statistical significance was calculated by one-way ANOVA comparing each knockout to the EV control. ${ }^{*}, p \leq 0.05 ;{ }^{* *}, p \leq 0.01 ;{ }^{* * *}$, $p \leq 0.001$.

656 This manuscript has been co-submitted with Kim et al. (2020), "Pancreatic Cancers Scavenge Hyaluronic Acid to Support Growth." 
bioRxiv preprint doi: https://doi.org/10.1101/2020.09.13.294116; this version posted June 21, 2021. The copyright holder for this preprint (which was not certified by peer review) is the author/funder. All rights reserved. No reuse allowed without permission.

A Soft agar colony assay

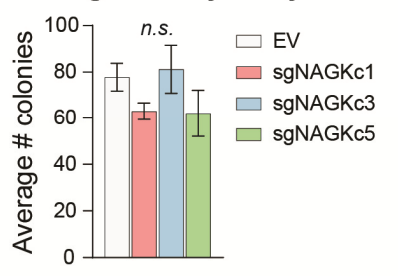

B
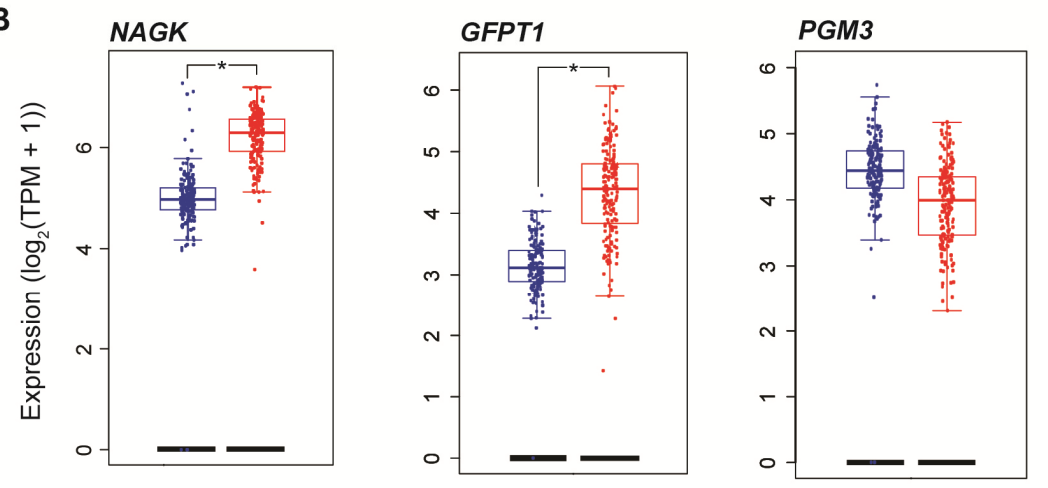

UAP1

C

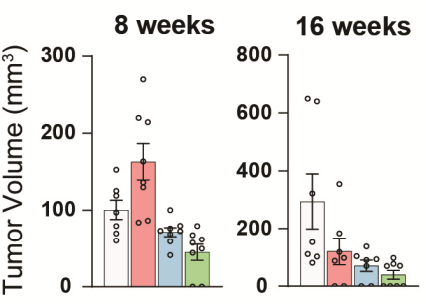

D $\square \mathrm{EV}$

$\square$ sgNAGKc1

$\square$ sgNAGKC3

$\square$ sgNAGKc5

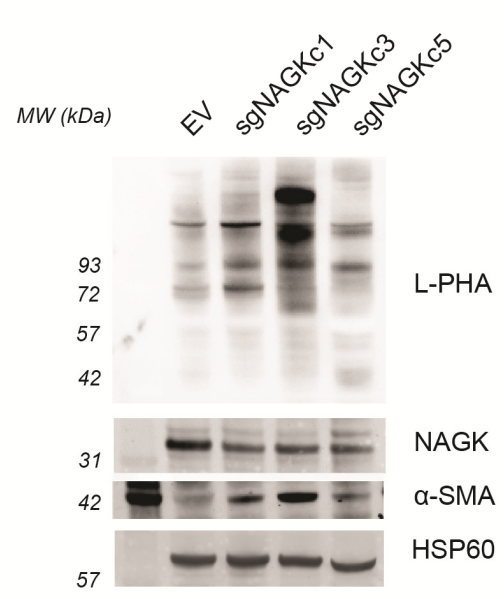

Supplementary Figure S4: NAGK knockout tumors show increased LPHA binding.

A) Soft agar colony formation in NAGK knockout and control cells. Mean +/- SEM of three biological replicates is represented. B) Gene expression data plotted using GEPIA2 comparing TCGA pancreatic cancer samples with TCGA normal pancreas samples and GTEx data. Differential analysis between tumor and normal tissues was analyzed by one-way ANOVA. ${ }^{*}, p<0.05$. C) Tumor volume of NAGK knockout tumors at earlier time points in the experiment. Initial growth of NAGK knockout cells in vivo was comparable to control cells, but over time NAGK knockout tumors either stopped growing or regressed. D) Western blots for NAGK and a-SMA, and blot probed for LPHA binding, in whole tumor lysate samples. Blot for HSP60 as loading control.

This manuscript has been co-submitted with Kim et al. (2020), "Pancreatic Cancers Scavenge Hyaluronic Acid to Support Growth." 